\title{
Biomarkers and Their Possible Functions in the Intestinal Microenvironment of Chagasic Megacolon: An Overview of the (Neuro)inflammatory Process
}

\author{
José Rodrigues do Carmo Neto ${ }^{\mathbb{D}},{ }^{1}$ Yarlla Loyane Lira Braga, ${ }^{1}$ \\ Arthur Wilson Florêncio da Costa, ${ }^{1}$ Fernanda Hélia Lucio, ${ }^{1}$ Thais Cardoso do Nascimento, ${ }^{1}$ \\ Marlene Antônia dos Reis, ${ }^{2}$ Mara Rubia Nunes Celes, ${ }^{1}$ Flávia Aparecida de Oliveira, ${ }^{1}$ \\ Juliana Reis Machado $\left(\mathbb{D},{ }^{1,2}\right.$ and Marcos Vinícius da Silva ${ }^{3}{ }^{3}$ \\ ${ }^{1}$ Department of Bioscience and Technology, Institute of Tropical Pathology and Public Health, Federal University of Goiás, Goiânia, \\ GO, Brazil \\ ${ }^{2}$ Department of General Pathology, Federal University of Triângulo Mineiro, Uberaba, Minas Gerais, Brazil \\ ${ }^{3}$ Department of Microbiology, Immunology and Parasitology, Institute of Biological and Natural Sciences, Federal University of \\ Triângulo Mineiro, Uberaba, Minas Gerais, Brazil
}

Correspondence should be addressed to Juliana Reis Machado; juliana.patologiageral@gmail.com

Received 25 December 2020; Revised 8 March 2021; Accepted 19 March 2021; Published 8 April 2021

Academic Editor: Márcia Laurenti

Copyright (c) 2021 José Rodrigues do Carmo Neto et al. This is an open access article distributed under the Creative Commons Attribution License, which permits unrestricted use, distribution, and reproduction in any medium, provided the original work is properly cited.

\begin{abstract}
The association between inflammatory processes and intestinal neuronal destruction during the progression of Chagasic megacolon is well established. However, many other components play essential roles, both in the long-term progression and control of the clinical status of patients infected with Trypanosoma cruzi. Components such as neuronal subpopulations, enteric glial cells, mast cells and their proteases, and homeostasis-related proteins from several organic systems (serotonin and galectins) are differentially involved in the progression of Chagasic megacolon. This review is aimed at revealing the characteristics of the intestinal microenvironment found in Chagasic megacolon by using different types of already used biomarkers. Information regarding these components may provide new therapeutic alternatives and improve the understanding of the association between T. cruzi infection and immune, endocrine, and neurological system changes.
\end{abstract}

\section{Introduction}

According to the World Health Organization (WHO), approximately 8 million people in the world are infected with Trypanosoma cruzi (T. cruzi), the etiological agent of Chagas disease (CD) (WHO, 2018). Most of these cases are concentrated in Latin America, where the number of new cases per year is estimated to be 300,000 [1]. In Brazil, at least one million people are infected with T. cruzi, and most of them are in the chronic phase [2]. Recently, the cases of acute $\mathrm{CD}$ have increased in Brazil, mainly owing to the consumption of food contaminated with parasites, such as açai and sugarcane juice $[3,4]$.
$\mathrm{CD}$ has two phases, acute and chronic. The acute phase is characterized by the high parasitic load with cellular destruction and extensive inflammatory foci [5]. Subsequently, the condition may progress to an undetermined or determined chronic phase of the disease, which may then lead to the development of severe cardiac and digestive dysfunctions and death [5]. The indeterminate chronic phase is characterized by positive serology and/or parasitology along with the absence of symptoms and/or signs caused by T. cruzi [5]. The symptomatic chronic phase can develop after few years to decades due to some unknown factors, in approximately $30 \%$ of the infected people. In this phase, mega syndromes could develop with cardiac (cardiomegaly) and/or digestive 
(megaesophagus and/or megacolon) involvement, in addition to neurological damage [5].

The first suspected case of the digestive form of $\mathrm{CD}$ appeared in 1916, when Carlos Chagas observed that in the acute infection some adults presented marked dysphagia, which was perpetuated in the chronic phase, and he called this "Choking Disease" [6]. Patients with the digestive form of CD present with hypertrophic changes with esophagus (megaesophagus) and/or intestinal colon (megacolon) dilation, leading to dysphagia, regurgitation, and motor discoordination. The main cause of dilation of these organs is their denervation owing to the destruction of myenteric or Auerbach and submucosal or Meissner plexus [7]. Different mechanisms have been proposed to explain this neuronal destruction, such as the release of toxins during parasite fragmentation, direct neuronal injury through cell parasitism, and inflammatory damage triggered by the parasite [8].

This review focuses on the intestinal biomarkers of Chagasic megacolon and their possible functions in CD progression, especially those related to (neuro) inflammatory processes. Despite the advances in the understanding of the CD evolution, cell interactions and molecular pathways involved in megacolon development/progression are not completely clear. Thus, the investigation of biomarkers of altered intestinal structures is also fundamental to understand the rich microenvironment of Chagasic megacolon and its relationship with disease pathogenesis, especially those related to neuronal death.

\section{An Immunological Overview of Chagasic Megacolon}

Chagasic megacolon is characterized by a hollow viscera with chronic constipation, followed by permanent pathological dilation of the organ wall, which usually occurs in the rectus sigmoid portion, where the parasite is commonly found [5]. From the morphological point of view, patients with megacolon present histological changes such as organ wall thickening due to severe muscle fiber hypertrophy, especially in the circular layer; these changes are usually associated with an inflammatory process in addition to the presence of hypertrophied neurons in the submucous and myenteric plexus and/or with the signs of degeneration [7].

The myenteric plexus is severely affected by the inflammatory process triggered by $T$. cruzi infection, resulting in decreased number of nerve cells or even complete destruction of nerve ganglia [7, 9]. The T. cruzi-induced intestinal inflammation led to neuron degeneration in the gastrointestinal system $[10,11]$ and ganglionitis, peri-ganglionitis, neuritis, and peri-neuritis in the myenteric plexus [7]. These lesions begin to form in the acute phase and are prolonged and aggravated during the chronic phase [12]. The inflammatory process related to this neuron degeneration usually has a focal distribution. However, some neurons close to the injured neurons remain intact [7].

The phenotypic characterization of the inflammatory infiltrate components led to a better understanding of the pathophysiology of Chagasic megacolon, although the process is not yet completely understood. Eosinophils, mast cells
(MCs) and their proteases, $\mathrm{CD}^{+} 8^{+}$macrophages, $\mathrm{CD} 57^{+}$natural killer cells, and TIA- $1^{+}$cytotoxic lymphocytes in the affected intestine are factors related to inflammatory process maintenance and neuronal death during the $\mathrm{CD}$ chronic phase $[8,13-15]$.

Over the years, some theories attempted to explain neuronal destruction in the different phases of infection. During the acute phase, the high concentration of the protozoan has been suggested to participate in neuronal death [8]. In contrast, in the chronic phase, in which minimal amount of $T$. cruzi is clearly demonstrated in the injured organ, neuronal destruction process would be the consequence of the (auto) immune response following infection [8]. According to this idea, as indeterminate form progresses to digestive form, peripheral blood mononuclear produces higher levels of IFN- $\gamma$, inducing TNF- $\alpha$ augmentation and a proinflammatory milieu in the intestine [16].

Cytokines such as TNF- $\alpha$ and IFN- $\gamma$ (produced mainly by Th1 lymphocytes) at the onset of infection are essential for parasites control as they are involved in the activation of microbicidal macrophages which produce reactive oxygen species (ROS) or nitric oxide (NO) $[17,18]$. However, a balanced response is essential so that the infection is controlled and does not result in excessive tissue damage.

In addition to lymphocytes, central or peripheral glial cells are potential sources of NO. They have been reported to participate in neuropathologies, leading to the production of neuron protective or toxic molecules $[19,20]$. In Chagasic megacolon, the alteration of the number of enteric glial cells, as well as glial activation markers, suggests that these cells participate in the inflammatory process and in the subsequent neuronal damage or protection $[15,21]$. Actually, glial cells have been shown to be parasitized by T. cruzi in both the central nervous system (CNS) and the enteric nervous system (ENS) [7, 22-25].

\section{Biomarkers in Chagasic Megacolon: Immune Response and Neuroinflammation}

In addition to glial cells and traditional immune system components, other components are also associated with the progression of or protection against Chagasic megacolon. Possible interactions between the nervous and immune systems that may be associated with different CD progression events, particularly those related to the maintenance of the inflammatory process and tissue damage, especially in the ENS, are discussed below.

3.1. Protein Gene Product. Initially described in 1981, protein gene product (PGP 9.5) is a cytoplasmic protein produced by central and peripheral neurons [26]. It is highly concentrated in intact neurons and can be used as a specific neuronal marker and, consequently, for neuronal density evaluation [27]. The use of PGP 9.5 neuronal marker confirmed the participation of the ENS in the pathophysiology of diseases related to neuronal damage, such as Hirschsprung's disease (HD) [28], ulcerative colitis [29], and intestinal neuronal dysplasia [30]. 
Due to the difficulty to establish experimental models for the digestive $\mathrm{CD}$, divergent results regarding PGP 9.5 have been published. The $\mathrm{C} 3 \mathrm{H} / \mathrm{He}$ mice, 30 days after infection (acute phase) with Brazil T. cruzi strain, did not reduce the intestinal neuronal PGP 9.5 staining as compared with control mice [31]. Similarly, C57Bl/6 mice, seven days after infection (acute phase), also showed no decrease of immunoreactive neurons for PGP 9.5 (IR-PGP 9.5) [32]. In contrast, $\mathrm{C} 57 \mathrm{Bl} / 6$ mice demonstrated a reduction in the neuron fibers and IR-PGP 9.5 neurons in the intestine, especially in the myenteric plexus, 10 days (acute phase) after infection with the Y strain [22].

Additionally, PGP 9.5 neuronal density was also investigated in chronic models of CD [33]. Infection of Swiss mice with Y strain for 11 days (acute phase) and 15 months (chronic phase, with the administration of a single dose of benznidazole at 11 days of infection) found that the infection reduced the density and number of IR-PGP 9.5 neurons in the intestine. Furthermore, the number of intramuscular IR-PGP 9.5 neuron fibers was lower in the chronic phase as compared to the acute phase [33].

Although most of the studies on PGP 9.5 neuronal density use the experimental models, da Silveira et al. [15] and Martins et al. [34] showed that patients chronically infected with megacolon presented reduced density of IR-PGP 9.5 nerve fibers in both, internal muscle layer and intestinal external muscle, as compared to nonmegacolon $\mathrm{CD}$ patients and noninfected.

3.2. Peripherin. Peripherin is a type III intermediate filament protein expressed in the cell body and axons of neurons, mainly in the peripheral nervous system [35-38]. Peripherin may play an important role in diseases such as amyotrophic lateral sclerosis [39-41] and type I diabetes mellitus [42-44]. In addition, peripherin plays a promising role as a panneural marker in the intestinal mucosa and submucosa [45].

Peripherin helps in the diagnosis of HD, as it is a part of the highly sensitive and specific ganglion cell identification protocol. Peripherin as neuronal biomarker is more sensitive and superior to microtubule-associated protein-2 (MAP-2) and calretinin in ganglion cell and nerve fibrillation marking in colon and rectum biopsies [46] so is specific method for identify HD patients [47].

The role of peripherin in $\mathrm{CD}$, as well as in other pathological processes, is not completely elucidated, and despite the controversies, this protein has been used as a standard for pan-neuronal staining in intestinal diseases $[45,48,49]$. Morphometric analysis of immunoreactive neuronal ganglia for peripherin in the colon from CD patients with megacolon showed reduction in this protein compared to that in healthy people, as it is related to decreased number of neurons. In addition, neuronal ganglia marked with this protein in $\mathrm{CD}$ patients showed a deformed structure [50].

In addition, peripherin seems to play a role in neuronal apoptosis through the interaction with protein kinase $\mathrm{C}$ [51]. Considering that one of the hypotheses for the development of CD megacolon is the cell death of mucosal neurons, peripherin may have an additional role in the pathogenesis of this disease.
3.3. $\mathrm{HuC} / \mathrm{HuDa}$. $\mathrm{HuC}$ and $\mathrm{HuDa}$ are RNA-binding proteins that are obtained by the alternative splicing of Hu RNA [52], exclusively expressed in neurons. These proteins are considered potent ENS neuron markers [53-55]. Anti-HuC/HuDa antibodies were used as neuronal markers to determine the total number of cell bodies in the nerve plexus of CD patients, pointing that the dilated portion of $\mathrm{CD}$ patients with megacolon had fewer neuronal bodies in each ganglion [56]. Similarly, $\mathrm{HuC} / \mathrm{HuDa}$ were also used as neuronal markers in the colon samples of CD patients in another study [57].

Thus, PGP 9.5, peripherin, and $\mathrm{HuC} / \mathrm{HuDa}$ were used to evaluate intestinal neuronal loss, especially in Chagasic megacolon, in addition to evaluation of neuronal density, providing a better picture on neuronal regeneration, subpopulation proportion, and cell colocation [58]. Furthermore, they represent an alternative to basic histological staining techniques, which are, in general, nonspecific [58].

3.4. Substance P. Substance P (SP) is a neuropeptide belonging to the tachykinin family [59, 60]. Expressed by several cell types, mainly neurons [61], this neuropeptide is involved in important inflammatory mechanisms, either in cell migration, where it acts directly, or through the induction of a series of chemokines, receptors and adhesion molecules in lymphocyte proliferation, and innate and adaptive immunity cell activation [62].

SP acts via the interaction with cell surface receptors NK1R, NK2, and NK3. NK1R has the greatest affinity for $\mathrm{SP}$, as it is predominantly related to inflammatory processes, whereas NK2 and NK3 receptors are more related to gastrointestinal motility responses $[63,64]$. In the intestine, SP regulates smooth muscle contractility, epithelial ion transport, vascular permeability, and gastrointestinal tract immune function $[65,66]$. NK1R receptor density was found to increase significantly in patients with Crohn's disease and ulcerative colitis [67]. These levels correlate with a poor prognosis of CD [68-70].

Substance $\mathrm{P}$ can cause neuroinflammation, since neurons also produce and respond to SP [66]. Classical neuroinflammatory responses are characterized by glial activation, microglial proliferation, leukocyte recruitment, and positive inflammatory mediator regulation and secretion [71]. In infectious diseases, SP increases the severity of inflammation associated with Trypanosoma brucei infection, etiological agent of sleeping sickness, for example, and treatment with an NK1R antagonist reduced this effect [72]. Similarly, this neuropeptide also contributed to the development of Taenia crassiceps infection in a neurocysticercosis model. Knockout mice for the SP precursor or its NK1 receptor had reduced granuloma volume and lower IL- $1 \beta$, TNF- $\alpha$, IL- 6 , and IFN- $\gamma$ expression [73]. NKR1 inhibition was also promising for the treatment of experimental autoimmune encephalomyelitis (EAE) [74], head trauma [75], and meningitis caused by S. pneumoniae [76]. NKR1 inhibition is a promising treatment for neuroinfectious and neuroinflammatory processes, with positive immune response effects in the nervous tissue, and several antagonists are being developed.

The SP expression has also been shown to be directly correlated with the severity of Chagasic megacolon. The SP 
expression has been shown to be high in the submucosa and myenteric plexus neurons in the dilated portion of Chagasic megacolon compared to that in the nondilated portions and noninfected people [56]. Moreover, in contrast to the high SP level, low NK1R receptor levels were observed in the dilated portion [77]. Conversely, other studies described lower myenteric and submucous plexus SP concentration in the rectum samples from CD patients. The authors associated this finding with the destruction of intestinal nerve ganglia [78]. Corroborating this study, SP staining activity was reduced in the neurons of the myenteric plexus of the colon in experimental models of acute and chronic infection with the $\mathrm{Y}[79,80]$.

In general, the role of SP in the immune response to $T$. cruzi infection is particularly remarkable. The increase of this neuropeptide in patients with megacolon may be related to the elimination of the parasite, which somehow accelerates the progression of the megaesophagus or colon due to increased inflammatory response. Besides, SP may have the ability to modulate the production of a wide range of cytokines. SP stimulates the production of proinflammatory cytokines such as IL- $1 \beta$, IL- 6 , and TNF- $\alpha$ by human peripheral mononuclear cells, inducing lymphocyte proliferation and immunoglobulin production $[62,65,81]$. This situation probably occurs due to positive NK1R regulation, since, while IL-12, IL-18, and TNF- $\alpha$ induce the NK1R expression in T cells [82]; IL-10 and TGF- $\beta$ decrease the NK1R expression [83]. The release of SP-induced inflammatory mediators potentiates tissue injury and stimulates leukocyte recruitment, amplifying the inflammatory response [84]. Thus, these studies suggest that the SP/NK1R axis maintains the inflammatory response to T. cruzi infection in CD, but no study has analyzed the effects of SP on intestinal Chagas neuroinflammation.

3.5. Growth-Associated Protein 43. Growth-associated protein-43 (GAP-43) is a marker of neuronal plasticity in embryogenesis processes, axonal growth and regeneration, and subsequent neurite branching [85]. GAP-43 has already been used in several intestinal disease models to evaluate neuronal plasticity, such as HD [86, 87], inflammatory bowel disease (IBD) [88], appendicitis [89], intestinal neuronal dysplasia [90], and Nippostrongylus brasiliensis infection [91]. These conditions are characterized by neuronal loss and establish an intestinal inflammatory process, which are also essential factors for the progression of Chagasic megacolon.

In fact, evidence shows that the neuronal regenerative process, evaluated using GAP-43 expression, occurs in the intestinal nervous plexus in Chagasic megacolon [50, 92]. Neuronal destruction mediated by the inflammatory process in the most affected areas is suggested to induce neurons to extend their projections into the destroyed areas to maintain intestinal homeostasis $[50,92]$. However, this regeneration would be restricted only to the most destroyed neural subpopulations in the intestinal form of $\mathrm{CD}$, corresponding to inhibitory motor neurons characterized by the expression of intestinal vasoactive peptide and NO synthase [50]. The same reestablishment would not occur for other subpopulations such as intrinsic primary afferent neurons, excitatory motor neurons, and interneurons since they are not considerably destroyed by the infectious process [50].

Although no studies have focused on GAP-43-related pathways in Chagasic megacolon, other axon injury models have been evaluated [93-96]. Some studies have shown that GAP-43 inhibition decreases axon regenerative capacity after injury [93]. In addition, the use of blockers to inhibit the GAP-43 process, such as Nogo-A-dependent processes, represents an alternative to induce increased axon regeneration [97-99]. Thus, studies on neuronal regeneration and plasticity in Chagasic megacolon may establish new mechanisms to control progression in the early stages of this form of CD.

3.6. S-100 Proteins and Glial Fibrillary Acidic Protein: Enteric Glial Cells. S-100 is a family of approximately 21 proteins characterized as small calcium-binding proteins [100]. Besides participating in $\mathrm{Ca}_{2}{ }^{+}$homeostasis, S-100 proteins have intracellular and extracellular functions, acting in an autocrine and/or paracrine manner in target cells [101] and act in cell proliferation, differentiation, and migration as well as inflammatory processes [102], and as cell markers, mainly of glial cells [103].

Although S-100 proteins are mainly used as a CNS astrocyte biomarker [104, 105], glial components of the ENS also showed reactivity for these proteins, which was not observed for intestinal neurons $[106,107]$. Thus, S-100 was characterized as a pan-glial marker also for the intestine.

Another important marker to visualize glial components, specifically astrocytes, is the glial fibrillary acidic protein (GFAP) [108]. Classified as the main intermediate filament protein of class III astrocytes, GFAP is related to the maintenance of cell structure and signal transduction [109]. In general, GFAP has been shown to play a role in cell motility, migration, and proliferation processes; chaperone-mediated autophagy; synaptic plasticity; neuronal damage or protection; and inflammation [108, 110]. Initially described as a CNS astrocyte marker, astrocyte-like enteric glial cells were also found to be immunoreactive for GFAP, especially in the intestinal nerve ganglia $[103,104,111]$.

Chagasic megacolon was characterized by decreased S-100 glial-IR cells in different intestinal nerve plexuses $[15,112,113]$. In addition, the dilated portion of the intestinal form of $\mathrm{CD}$ is described as having greater glial destruction (IR-S-100) than the nondilated one $[15,21,114]$. Interestingly, the GFAP marker increased the number of glial cell immunoreactive for this protein in T. cruzi infection, regardless of intestinal involvement $[15,21]$. However, the number of IR-GFAP glial cells in CD patients without megacolon or in the nondilated part of the intestine of CD patients was higher than that in the affected part $[15,21]$. Thus, considering that unaffected intestinal segments would have greater glial cell preservation, the presence of these cells has been suggested to protect ENS components from the inflammatory process established by $T$. cruzi infection $[15,21]$.

In fact, enteric glial cells and their products participate in intestinal homeostasis, especially in neuronal survival. Thus, the reduction of these cells has already been suggested to be associated with infectious $[115,116]$ and noninfectious intestinal diseases [117-119], which are characterized by 
neurodegeneration, like in $\mathrm{CD}$. Evidence shows a glial cell and neuron network owing to the production of NTs such as NGF, NT-3/4/5, and glial cell line-derived neurotrophic factor (GDNF). These neurotrophic factors directly and positively affect neuronal growth, maturation, and survival [120, 121]. Whether these molecules could protect neurons was also evaluated in the digestive form of CD [112]. Interestingly, the levels of NT-3, NGF, and GDNF were higher in the intestine of $\mathrm{CD}$ patients without megacolon, and this increase was correlated with the increase in the number of IR-GFAP glial cells and ENS cell protection [112]. In addition, along with the glial system, neurons and inflammatory infiltrate also increased NT production, increasing the relationship between the immune and nervous systems [112]. Thus, the authors suggested that the inflammation found in the intestine of $\mathrm{CD}$ patients without megacolon is determinant for NT production and that the increased enteric glial cells would facilitate the reestablishment of the integrity and functioning of the intestine after T. cruzi infection and the regulation of the established inflammatory process.

Similar to CNS astrocytes, enteric glial cells are sensitive to the stimuli of inflammatory processes. Proinflammatory cytokines such as IL- $1 \beta$, TNF- $\alpha$, and IFN- $\alpha$ can induce GFAP $[122,123]$ and NT production [124] and act on in vitro proliferation of these cells, which could justify the results found in the intestine of patients infected with $T$. cruzi. Additionally, experimental models of intestinal inflammation showed that inflammation induces enteric glial cell proliferation in the myenteric plexus and that the lack of these cells results in severe tissue inflammation and intestinal necrosis $[125,126]$. Conversely, enteric glial cells (ECGs) can also produce inflammatory mediators and exacerbate the intestinal inflammatory process [122, 127-129].

In fact, the microglia phenotype in the CNS is directly related to the microenvironment to which these cells are exposed [130]. When these cells are stimulated with proinflammatory components such as IFN- $\gamma$, TNF- $\alpha$, and IL-17, the microglia polarize to the M1-like profile and can produce NO, ROS, and proinflammatory cytokines (IL-1, IL-12, and TNF- $\alpha$ ) related to neurotoxicity and neuronal death. In contrast, once IL-4 and IL-13 stimulate these cells, the M2-like profile is established in the microglia. This activation profile is related to IL-10, TGF- $\beta$, and NT production (NT-3, NGF, and GDNF), which is related to neuroprotection and neuronal survival. Although this classification was not noted for EGCs, evaluating intestinal subpopulations and glial plasticity in $\mathrm{CD}$, especially comparing infected patients with and without megacolon, is important.

In addition, analysis of neurodegeneration and inflammatory processes showed that CNS microglia cells express molecules originally found in macrophages, such as class II HLA-DR, B7.1, and B7.2, indicating how these cells interact with the immune system as antigen-presenting cells. In fact, in $\mathrm{CD}$ patients with megacolon, EGCs begin to express class II HLA-DR and B7 costimulating molecules [49]. These results suggest that the established inflammatory process would affect the profile of EGCs that could act on lymphocyte activation in the intestine of patients with megacolon [49]. The presence of macrophages and lymphocytes was often associated with the severity of Chagasic megacolon [13]. Thus, EGCs also influence the progression of chronic digestive $\mathrm{CD}$ as antigen-presenting cells, consequently acting on lymphocyte activation [49].

These results suggest that the progression of intestinal $\mathrm{CD}$ depends on the microenvironment of the intestinal segment (with or without megacolon; Figure 1). The presence of a greater inflammatory infiltrate, a higher level of proinflammatory cytokines, and tissue destruction may indicate that EGCs would maintain the inflammatory process and neuronal destruction in Chagasic megacolon. The opposite could be assumed for patients without the digestive form, with lower organ involvement and greater quantity of enteric glia reestablishing the intestinal homeostasis. Further studies are needed to determine the role of EGCs in the acute phase of the disease and to elucidate whether this phase would be the determinant for the activation, destruction, and subsequent participation of the glia in the development of Chagasic megacolon, as well as whether the activation profile of these cells in the intestine of T. cruzi-infected patients in the chronic phase is M1- or M2-like.

3.7. Tryptase and Chymase: Mast Cells. Tryptase and chymase are the main serine proteases secreted by MCs; they mainly act as a factor to evaluate MC activation and classification in humans and mice [131, 132]. In general, tryptase and chymase are mainly involved in extracellular matrix degradation processes, tissue remodeling, and fibrosis [133-136] and have a dualistic role in inflammatory processes [137].

In fact, MCs play an important role in megacolon pathophysiology. Evidence shows that the concentration of these cells is increased regardless of the affected intestine layer $[13,34,138,139]$; the same has been observed in a murine chronic phase model [140]. The increase in chymase-IR and tryptase-IR MCs has been shown to be correlated with decreased PGP 9.5-IR neurons in Chagasic megacolon [34]. In addition, only increased tryptase-IR MCs (and not chymase-IR MCs) were correlated with decreased PAR2-IR neurons. This receptor is cleaved by tryptase and participates in hyperactivation and neuronal death, triggering chronic intestinal function changes [141]. Also, there is a proximity between MCs in active degranulation (fragmented and anaphylactic) and intestinal nerve fibers, and the subsequent neuronal death could be partially mediated by the tryptase enzyme released through MC degranulation in Chagasic megacolon, and both proteases would be involved in the maintenance of the inflammatory process in the organ [34].

The communication between MCs and neurons in the intestine has already been reported in other studies [141144], suggesting an important interface between the immune and nervous systems [145]. MC degranulation was found to be associated with nerve fiber network disintegration and loss of neuronal cell bodies in a coculture model between myenteric neurons and peritoneal MCs isolated from rats [146], and besides tryptase, other proinflammatory MC mediators such as IL-6 and prostaglandin 2 could induce neuronal death. The same was observed when a PAR2 agonist was used [146], corroborating what was suggested by Martins et al. [34] in Chagasic megacolon. 
(a)
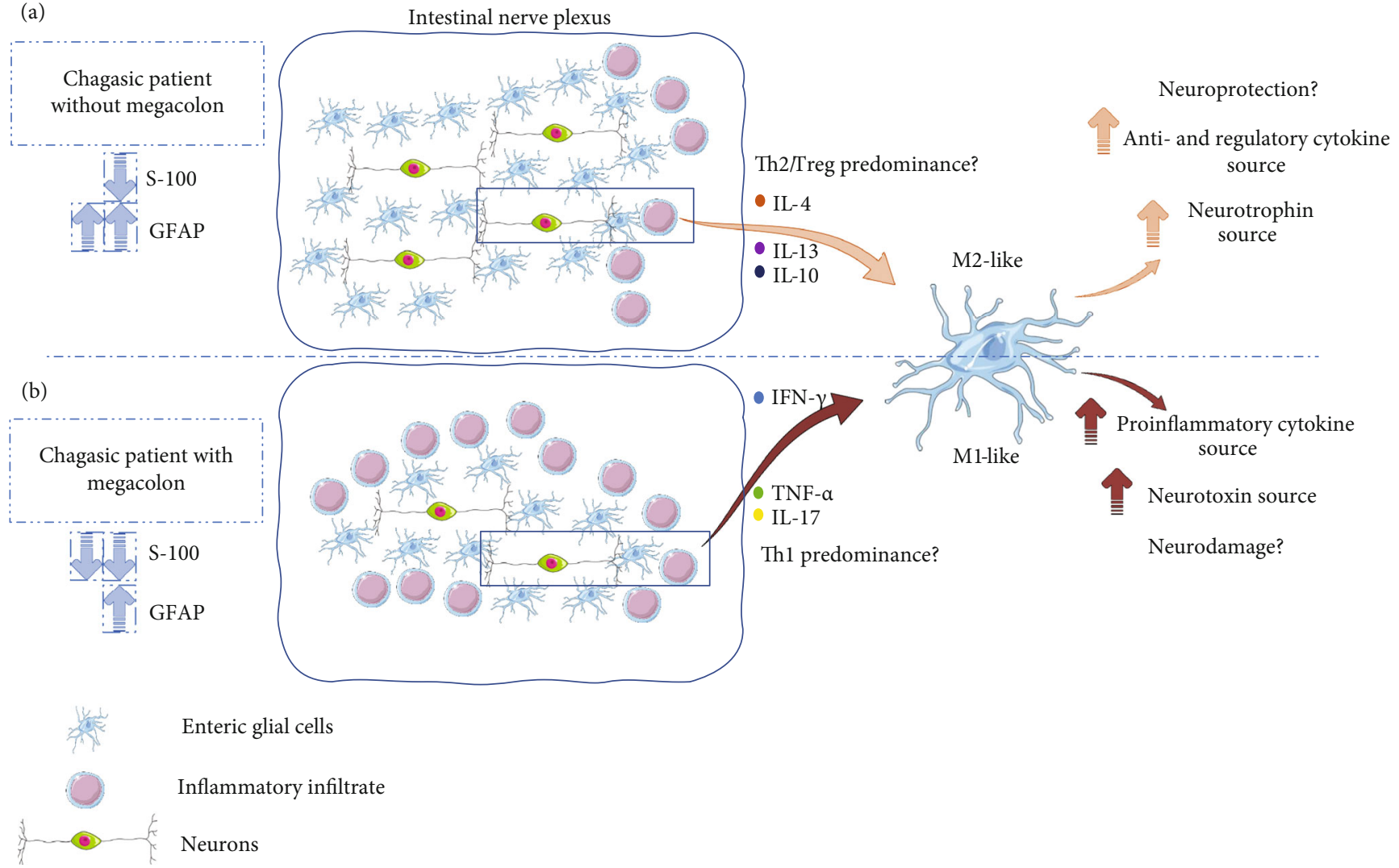

FIGURE 1: Hypothetical scheme of the differential behavior of enteric glial cells in the intestine of infected patients without megacolon (a) and with megacolon (b). This work, "Hypothetical scheme of the differential behavior of enteric glial cells in the intestine of infected patients without megacolon (a) and with megacolon (b)," is a derivative of "Servier Medical Art" by Servier, used under CC BY 3.0.

Neuropeptides have also been shown to activate MCs, which further confirms the participation of this cellular type in nervous system inflammation [147], such as SP in experimental dermatitis model [148] and irritable bowel syndrome [149]. Thus, the increased SP-IR neurons found in Chagasic megacolon are thought to be correlated with MC degranulation in the affected organ, subsequently releasing proinflammatory mediators such as TNF- $\alpha$, IL- $1 \beta$, and tryptase, which reinforced the relation between MCs, tryptase, neuroinflammation, and neuronal death.

Moreover, tryptase was suggested to participate in the inflammatory cell transmigration process [150-153]. Lung allergy [154, 155], psoriasis [156], asthma [157], and CD models [158] showed that this protease is a potential component in eosinophilic infiltration. The increased tryptase-IR MCs in the myenteric plexus and internal muscle layer were positively correlated with increased eosinophils in the same regions in Chagasic megacolon [158] and showed cell proximity under electron microscopy, suggesting a possible communication between MCs and eosinophils via PAR2. The role of MCs-eosinophil communication during the T. cruzi infection is unknown, but MCs are believed to participate in eosinophil survival in Chagasic megacolon [158]. However, MCs-eosinophil cells interact through the production of mediators such as histamine, eotaxin, and tryptase produced by MCs [159] and via physical contact in other intestinal diseases [160]. A decreased eosinophil infiltration was also observed under MC deficiency conditions [161], which reinforces the communication between these two cell types.

The presence of eosinophils in the in vitro and/or in vivo CD study models in humans was associated with protozoan destruction and control, tissue damage, and inflammatory process maintenance in both the acute and chronic phases of the disease [162-168]. In addition, this cell type was correlated with intestinal fibrosis in the nerve plexus and muscle layers of patients with megacolon, regions that showed an increased level of eosinophils compared to that in noninfected people and infected patients without megacolon [13]. The dual role of these cells in the affected intestine has been discussed. Increased eosinophils would allow (1) returning to intestinal homeostasis or/and (2) controlling the infection and consequently resulting in tissue damage.

The role of chymase in the inflammatory process is not yet clear. Evidence suggests that it participates in the pathophysiology of intestinal inflammatory diseases such as IBD [169] and protozoan [170] and helminth infections [171]. Therefore, the blockade of this protease is related to an improved intestinal inflammatory status [172, 173], which was related to increased IL-10, TGF- $\beta$, IL-17A, and T regulatory lymphocyte production in experimental IBD in rats [174].

In contrast, the expression of mast cell chymase gene (CMA1) was shown to be associated with increased IL-10 
in an experimental chronic intestinal stress model [175], suggesting its regulatory role in the inflammatory process. In addition, a murine sepsis model showed that the mast cell protease 4 (corresponding to chymase in humans) degrades TNF- $\alpha$, limiting the proinflammatory effect of this cytokine, which increased the survival of the animals [176]. The functions of these proteases are apparently dependent on the location of MCs producing it, which also varies according to the pathophysiology of each disease studied.

Besides the inflammatory process, chymase participates in tissue remodeling via TGF- $\beta$ and metalloproteinases in different organs and pathological conditions $[177,178]$. The presence of intestinal MCs in Chagasic megacolon is positively correlated with organ fibrosis [13]. Thus, increased chymase in the chronic phase of CD may represent a pathway for intestinal collagen deposition according to disease progression. However, little is known about this function in Chagasic megacolon.

Proteases produced by enteric MCs represent a source of therapeutic targets for Chagasic megacolon. Thus, further studies are needed to elucidate more completely the mechanisms involving these cells and their products since they can be related to several processes that affect the progression of Chagasic megacolon (Figure 2).

3.8. Galectins. Galectins are proteins of the lectin family that have high affinity for the $\beta$-galactoside residues present in the components of the extracellular matrix (ECM). Although all cells express galectins, the amount expressed varies according to cell type, tissue, and microenvironment. Approximately 15 types of galectins have been reported in vertebrates, with different body functions [179]. In general, these proteins are related to homeostasis conditions, inflammatory processes, and interactions with ECM components and between cells, cell adhesion, and fibrogenesis.

Changes in galectin levels were correlated with the progression and worse prognosis of intestinal diseases such as colorectal cancer, colorectal adenoma, rectal cancer, and Crohn's disease [180]. In CD, galectin-1 (gal-1) and galectin-3 (gal-3) production was analyzed in experimental in vitro cardiac form models and in infected patients with Chagas heart disease in the acute and chronic phases [181]. Information regarding the profile and function of these proteins in the megacolon is lacking.

Beghini et al. [182] were the first to show changed gal-1, gal-3, and gal-9 levels in the intestine of T. cruzi-infected patients with megacolon. The authors reported that these three galectins were highly expressed only in the myenteric plexus of patients with the digestive form of CD compared to those who were not infected. In addition, to better establish the gal-3 profile in Chagasic megacolon, Garvil et al. [183] analyzed the protein expression in the intestine of megacolon patients with intact or injured mucosa and in people without infection with an intact mucosa. Regardless of mucosal integrity, patients with Chagasic megacolon had more gal-3-marked cells [183]. Both studies suggested the potential functions of galectin in Chagasic megacolon.

Studies have shown that gal-1 has an ambiguous role in the course of T. cruzi infection, either acting in a protective or detrimental manner. An in vitro cardiomyocyte infection model showed that the use of endogenous gal-1 inhibited $T$. cruzi infection [184]. The same study showed that gal-1deficient mice had higher parasitemia, less tissue inflammation, and lower survival than wild mice, suggesting an important role of gal-1 in protection against infection [184]. In contrast, another study showed that this galectin can induce anergy and form dendritic and $\mathrm{T}$ regulatory tolerogenic lymphocyte cells in mice with acute $T$. cruzi infection. This would impair Th1 response, which is important for controlling infection, thereby increasing parasite persistence in the tissues [185].

Besides its impact on the course of infection, gal-1 was also found to be related to neuroprotection in neuroinflammatory diseases [186]. Thus, the increase of this galectin in Chagasic megacolon could be to protect the ENS and control the neuroinflammatory process. In a murine multiple sclerosis model knockout for gal-1, extracellular gal-1 and also gal-9 could induce Th1 and Th17 lymphocyte apoptosis, which decreased the established inflammatory process [187, 188]. In addition, the administration of endogenous gal-1 in this same wild murine model inhibited microglia activation for the M1-like profile (important in EAE pathophysiology), favoring M2-like polarization and neuroprotection in this pathology [189]. Gal-1 also induces macrophages to produce NTs, stimulates the regenerative process of axons, and facilitates Schwann cell migration to injured peripheral nerves [190]. Thus, future studies need to elucidate the role of gal-1 in the inflammatory process in the chronic phase of $\mathrm{CD}$ and its relationship with ENS components.

Considering that Gal-3 level increases in the myenteric plexus of $\mathrm{CD}$ patients with megacolon, its role in facilitating the establishment of cell invasion at the early stages of infection, maintenance of the inflammatory process, and induction of fibrosis in the intestine has been discussed [182, 183]. In fact, these processes were already revealed in experimental Chagas cardiopathy models, in which the increase of this lectin was found to be directly related to increased inflammatory processes and cardiac fibrosis. Gal-3 also has a relationship with MCs by inducing their degranulation, a process involved in collagen fiber formation and tissue remodeling by tryptase [191]. Thus, gal-3 could have a detrimental role in the Chagasic megacolon and could be involved in the progression of the digestive form in both the persistence of the inflammatory process and the induction of tissue remodeling.

Gal-3 also plays an essential role in neuroinflammation [186], a process that may represent a new pathway for the maintenance of the neural inflammatory process in Chagasic megacolon. An experimental EAE model with a knockout phenotype for gal-3 suggested that this lectin would exacerbate the inflammatory process of the disease by increasing IL-17 and IFN- $\gamma$ and decreasing IL-10 [192]. As for the ENS, a murine stroke model (middle cerebral artery occlusion) showed that serum from $\mathrm{C} 57 \mathrm{Bl} / 6$ mice overexpressing gal-3 decreased the in vitro survival of intestinal myenteric neurons [193]. The same was observed when these cells were exposed to purified gal-3 [193]. Finally, the authors concluded that gal-3 release in the central and peripheral 

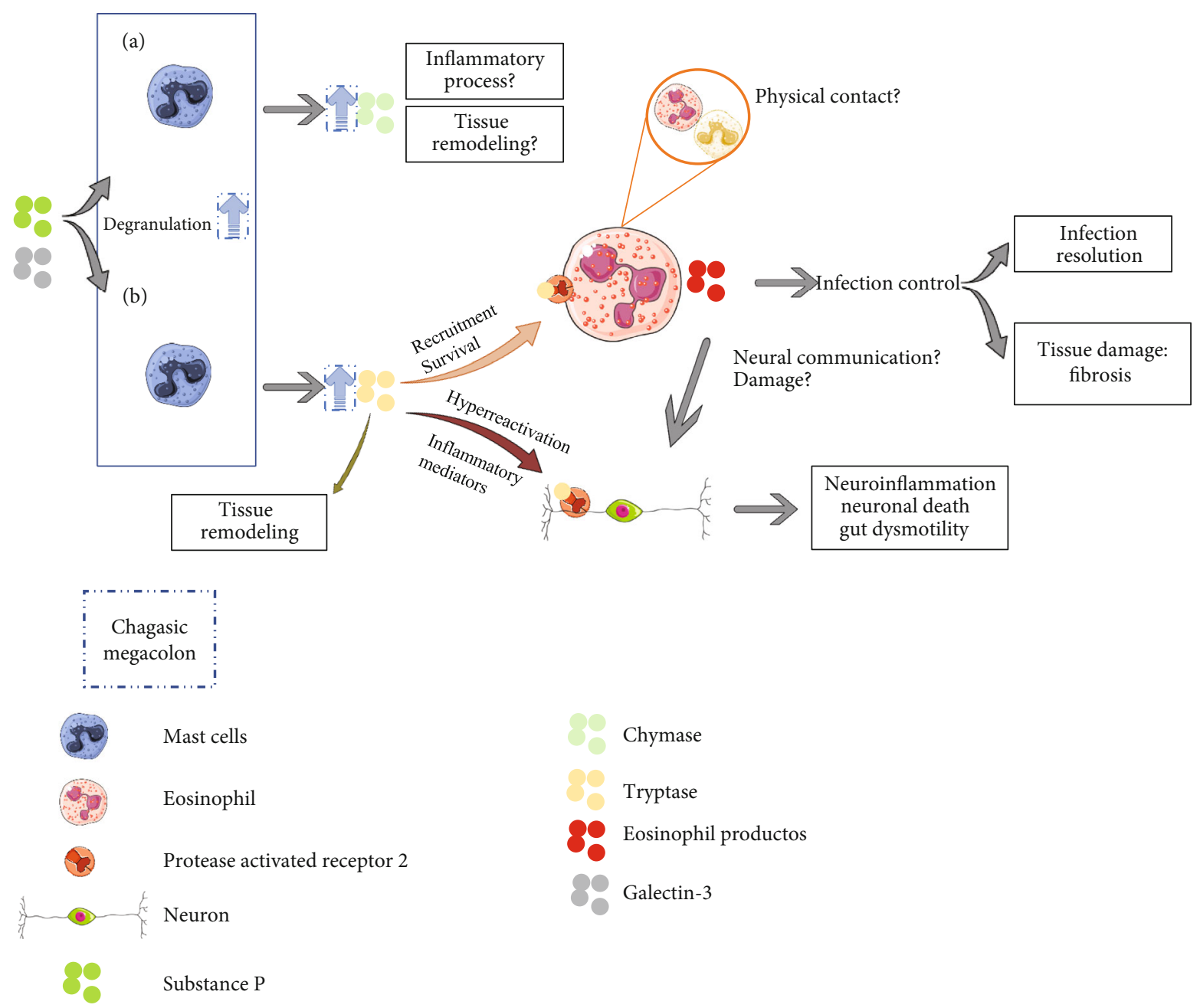

FIgure 2: Possible functions of mast cells and chymase (a) and tryptase (b) proteases in Chagasic megacolon. This work, "Possible functions of mast cells and chymase (a) and tryptase (b) proteases in Chagasic megacolon," is a derivative of "Servier Medical Art" by Servier, used under CC BY 3.0.

nervous systems would be directly related to intestinal neuronal death via toll-like receptor 4 , an innate immunity receptor previously related to death induction in neurons [193]. Future studies need to focus on identifying gal-3 inhibitors for the control and treatment of CNS neuroinflammatory pathologies [194]. Thus, the use and search for these inhibitors may also represent alternatives for ENS-related diseases such as Chagasic megacolon.

Further studies are needed to elucidate the role of galectins in the digestive form of CD, as most of the studies available are related to cardiac changes. In general, these lectins may also mediate the interaction between the immune and nervous systems, suggesting new therapeutic targets based on gal-3 blockade or even gal-1 or gal-9 administration [186].

3.9. Serotonin and Receptors. Serotonin, or 5hydroxytryptamine (5-HT), was initially discovered as a part of the coagulation process [195] and was later described in the homeostasis of several tissues such as the CNS [196] and the intestine [197, 198]. Enterochromaffin cells (ECs) of the intestinal mucosa synthesize, store, and release most of the serotonin in the body near the terminal of intestinal nerves [199, 200]. Other intestinal components such as enteric neurons and myenteric plexus cells also produce serotonin [201]. In addition, immune cells, enterocytes, and enteric neurons can express different subtypes of 5-HT receptors activated by $5-\mathrm{HT}$, which reveals the connection between the three systems: neuronal, immune, and endocrine [202]. Serotonin is known to be important in the modulation of the inflammatory process.

Changes in serotonin levels and metabolism receptors and intermediates were related to the progression of gastrointestinal diseases such as irritable bowel syndrome [203], IBD [204], celiac disease [205], and intestinal infectious diseases such as Vibrio cholerae [206, 207], Salmonella typhimurium [208], and Trichinella spiralis [209] infections. Changes in serotonin metabolism were shown to be related to the induction of inflammation and intestinal physiological changes [210].

Discordant evidence shows that the role of serotonin in $\mathrm{CD}$ depends on the progression of the digestive form. Some studies suggest that serotonin plays an anti-inflammatory role in the intestine of $T$. cruzi-infected patients without organ involvement, in which serotonin level is high and $B$ 
TABLE 1: Intestinal microenvironment and biological behavior of the components involved in the pathophysiology of Chagasic megacolon.

\begin{tabular}{|c|c|c|c|c|}
\hline $\begin{array}{l}\text { Biomarker or } \\
\text { techniques }\end{array}$ & Markers & Behavior & Supposed participation in the pathogenesis & References \\
\hline PGP 9.5 & Pan-neural & $\downarrow$ & \multirow{4}{*}{$\begin{array}{l}\text { Destruction induced by the parasite and the inflammatory } \\
\text { process established in the intestine. It affects intestinal motility } \\
\text { and is involved with fecal stasis, organ dilation, and Chagasic } \\
\text { megacolon progression. }\end{array}$} & {$[15,34]$} \\
\hline \multirow{2}{*}{ Peripherin } & Pan-neural & $\downarrow$ & & {$[50,112]$} \\
\hline & Disregarded & - & & {$[48,57]$} \\
\hline $\mathrm{HuC} / \mathrm{HuDa}$ & Pan-neural & $\downarrow$ & & {$[56]$} \\
\hline Substance P & Excitatory motor neurons (SP) & $\uparrow$ & Maintenance of the intestinal proinflammatory profile. & {$[56,77]$} \\
\hline \multirow[t]{4}{*}{ GAP-43 } & $\begin{array}{l}\text { Excitatory motor neuron } \\
\text { regeneration (GAP-43/SP and } \\
\text { GAP-43/cCHAT) }\end{array}$ & $=$ & \multirow{4}{*}{$\begin{array}{l}\text { The greatest regeneration found in the subpopulations of } \\
\text { inhibitory motor neurons (GAP-43/VIP and GAP-43/NO) is } \\
\text { related to the greater destruction of these cell types when } \\
\text { compared to the other subpopulations, which do not suffer } \\
\text { reduction. Thus, through compensatory mechanisms, the } \\
\text { subpopulation of inhibitory neurons tries to be reestablished, } \\
\text { and due to this, there is only an increase in this subpopulation. }\end{array}$} & \multirow{4}{*}[50]{} \\
\hline & $\begin{array}{l}\text { Inhibitory motor neuron } \\
\text { regeneration (GAP-43/VIP and } \\
\text { GAP-43/NO) }\end{array}$ & $\uparrow$ & & \\
\hline & $\begin{array}{l}\text { Intrinsic primary afferent } \\
\text { neuron regeneration } \\
\text { (GAP-43/calretinin) }\end{array}$ & $=$ & & \\
\hline & $\begin{array}{l}\text { Interneuron regeneration } \\
\text { (GAP-43/neuropeptide Y) }\end{array}$ & $=$ & & \\
\hline S-100 & Enteric glial cells & $\downarrow$ & Infection focus in the intestine. & $\begin{array}{l}{[15,21,} \\
114]\end{array}$ \\
\hline GFAP & Enteric activated glial cells & $\uparrow$ & \multirow[t]{3}{*}{$\begin{array}{l}\text { Increased activation of this cell type in an attempt to control } \\
\text { the infection through the production of proinflammatory and } \\
\text { microbicidal components, which leads to neurotoxicity } \\
\text { or/and increased activation of this cell type in an attempt to } \\
\text { control the inflammatory process through the production of } \\
\text { anti and regulatory cytokines and neuroprotective } \\
\text { components. }\end{array}$} & {$[15,21]$} \\
\hline $\mathrm{CD}^{+}$ & T lymphocyte & $\uparrow$ & & \\
\hline $\mathrm{CD} 20^{+}$ & B lymphocyte & $\uparrow$ & & {$[8,15]$} \\
\hline $\mathrm{CD} 68^{+}$ & Macrophage & $\uparrow$ & \multirow[t]{3}{*}{ Participation of the immune response in neuronal loss. } & \\
\hline $\mathrm{CD}_{5} 7^{+}$ & Natural killer cell & $\uparrow$ & & {$[15]$} \\
\hline TIA- $1+$ & Cytotoxic lymphocyte & $\uparrow$ & & \\
\hline $\begin{array}{l}\text { Hematoxylin- } \\
\text { eosin section }\end{array}$ & Eosinophil & $\uparrow$ & \multirow{2}{*}{$\begin{array}{l}\text { Participation of the immune response in neuronal loss and } \\
\text { intestinal remodeling. }\end{array}$} & {$[13]$} \\
\hline $\begin{array}{l}\text { Giemsa/toluidine } \\
\text { blue section }\end{array}$ & Mast cell & $\uparrow$ & & {$[13,139]$} \\
\hline Serotonin & Serotonin-producing cells & $\downarrow$ & \multirow{3}{*}{$\begin{array}{l}\text { Duality between the anti-inflammatory and proinflammatory } \\
\text { role of the components. }\end{array}$} & {$[138,211]$} \\
\hline & & $\uparrow$ & & {$[32]$} \\
\hline 5-HT3a receiver & $\begin{array}{l}\text { Lymphocytes producing } 5 \text {-HT3a } \\
\text { receptor }\end{array}$ & $\downarrow$ & & {$[212]$} \\
\hline Tryptase & Tryptase-producing mast cells & $\uparrow$ & \multirow{2}{*}{$\begin{array}{l}\text { Participation in neuronal damage, maintenance of the } \\
\text { inflammatory process, and tissue remodeling in the intestine. }\end{array}$} & {$[34,158]$} \\
\hline Chymase & Chymase-producing mast cells & $\uparrow$ & & {$[34]$} \\
\hline Galectin- 1 and -9 & Galectins & $\uparrow$ & Neuroprotection and infection control. & {$[182]$} \\
\hline Galectin-3 & Galectins & $\uparrow$ & $\begin{array}{c}\text { Maintenance of the inflammatory process, } \\
\text { neuroinflammation, and fibrosis. }\end{array}$ & {$[182,183]$} \\
\hline
\end{tabular}

$\uparrow:$ increased component compared to healthy intestine without T. cruzi infection; $\downarrow$ : decreased component compared to healthy intestine without T. cruzi infection; =: no component change compared to healthy intestine without $T$. cruzi infection.

and T lymphocyte [211] and MC [138] levels are low. The opposite was observed in megacolon, in which the amount of these inflammatory cells was higher than that of serotonin $[138,211]$. In contrast, the serotonergic activity was greater in the intestinal crypt cells in Chagasic megacolon than in noninfected people and patients with idiopathic megacolon [32].
The anti-inflammatory function of serotonin was reinforced by showing that lymphocytes present in the intestine of infected patients without megacolon expressed greater amount of serotonin's 5-HT3A receptor than those in patients with megacolon [212]. In addition, $\mathrm{CD}^{+}$and $\mathrm{CD} 20^{+}$lymphocytes were higher in the most severe form than in the nondigestive form of CD [212]. These results 
corroborate the initial discussion on the immune suppressor role of serotonin $[138,211]$. They also contribute to the development of a new pathway, in which this molecule would act on lymphocytes via the 5-HT3A receptor, leading to the inhibition of these cells. This would prevent the exacerbated immune response in CD patients without megacolon [212].

However, more information regarding the role of serotonin in the acute and chronic phases of CD is needed. The diversity of results found with either increased or decreased serotonin in Chagasic megacolon can be attributed to the methodological differences related to the phase of the disease, comparative groups, and experimental models used in each study.

A summary of biomarkers potentially involved in digestive CD establishment and/or progression is presented in Table 1.

\section{Outstanding Questions for Further Scrutiny}

The data discussed in this review raises the following questions to help clarify the several components involved in the intestinal form of $\mathrm{CD}$ :

(i) Does the activation of ECGs with a proinflammatory profile precede neural destruction in Chagasic megacolon? What is the behavior of ECGs in the acute phase of CD?

(ii) Do ECGs influence intestinal motility and mucosal changes in Chagasic megacolon?

(iii) Are ECGs protective or harmful in the progression of Chagasic megacolon?

(iv) Would it be possible to stimulate neuronal regeneration in the intestine of CD patients with megacolon?

(v) Does serotonin have different effects in acute and chronic phases of T. cruzi infection? What is the relationship between serotonin and immune system activation or inhibition in Chagasic megacolon?

(vi) Would MC enzymes, such as tryptase, be another neuronal cell death mechanism and maintaining the inflammatory perfil in Chagasic megacolon?

(vii) What is the function of chymase in intestinal tissue remodeling in Chagasic megacolon?

(viii) Would galectins be involved in the maintenance of the inflammatory process and intestinal remodeling in $\mathrm{CD}$ patients with megacolon?

(ix) What is the role of galectins in the protection or intestinal neuronal damage in $\mathrm{CD}$ ?

The answer to any of these questions may be related to the development of new therapies to prevent, improve, or even reverse the severity of Chagasic megacolon.

\section{Conclusion}

Although over 100 years have passed since the discovery of $\mathrm{CD}$, little is known about the specific mechanism of Chagasic megacolon pathogenesis. This review shows that Chagasic patients with or without megacolon have a rich and differentiated intestinal microenvironment. Additionally, the participation of neurons, glial cells, MCs, eosinophils, and proteins addressed in this review reveals the high complexity of Chagasic megacolon pathology. The progression of the digestive form of T. cruzi infection is associated with different components that circulate and interact with the immunological, endocrine, and neurological systems. Glial cells and MCs are potential participants in its systems since they are sensitive to stimuli such as proinflammatory cytokines, serotonin, and galectins. Thus, a more profound analysis of these components could contribute to clinical management and the identification of new therapeutic targets.

\section{Data Availability}

All the data used to support the findings of this study are included within the article and references.

\section{Conflicts of Interest}

The authors declare that there is no conflict of interest regarding the publication of this review article.

\section{References}

[1] M. C. P. Nunes, A. Beaton, H. Acquatella et al., "Chagas cardiomyopathy: an update of current clinical knowledge and management: a scientific statement from the American Heart Association," Circulation, vol. 138, no. 12, pp. e169-e209, 2018.

[2] A. da Silva Sousa Júnior, V. R. d. C. M. Palácios, C. d. S. Miranda et al., "Análise espaço-temporal da doença de Chagas e seus fatores de risco ambientais e demográficos no município de Barcarena, Pará, Brasil," Revista Brasileira de Epidemiologia, vol. 20, no. 4, pp. 742-755, 2017.

[3] A. Vargas, J. M. A. S. Malta, V. M. Costa et al., "Investigação de surto de doença de Chagas aguda na região extra-amazônica, Rio Grande do Norte, Brasil, 2016," Cadernos de Saúde Pública, vol. 34, no. 1, 2018.

[4] G. H. F. Sampaio, A. N. B. da Silva, C. R. D. N. Brito et al., "Epidemiological profile of acute Chagas disease in individuals infected by oral transmission in Northern Brazil," Revista da Sociedade Brasileira de Medicina Tropical, vol. 53, 2020.

[5] J. A. Pérez-Molina and I. Molina, "Chagas disease," The Lancet, vol. 391, no. 10115, pp. 82-94, 2018.

[6] C. Chagas, "Processos patojenicos da tripanozomiase americana," Memórias do Instituto Oswaldo Cruz, vol. 8, no. 2, pp. 5-36, 1916.

[7] W. L. Tafuri, "Light and electron microscope studies of the autonomic nervous system in experimental and human American trypanosomiasis," Virchows Archiv Abteilung A Pathologische Anatomie, vol. 354, no. 2, pp. 136-149, 1971.

[8] C. E. P. Corbett, U. Ribeiro, M. G. Prianti, A. Habr-Gama, M. Okumura, and J. Gama-Rodrigues, "Cell-mediated immune response in megacolon from patients with chronic Chagas' disease," Diseases of the Colon \& Rectum, vol. 44, no. 7, pp. 993-998, 2001. 
[9] S. J. Adad, D. C. S. Andrade, E. R. Lopes, and E. Chapadeiro, "Pathological anatomy of chagasic megaesophagus," Revista do Instituto de Medicina Tropical de São Paulo, vol. 33, no. 6, pp. 443-450, 1991.

[10] M. M. De Souza, S. G. Andrade, A. A. Barbosa Jr, R. T. M. Santos, V. A. F. Alves, and Z. A. Andrade, "Trypanosoma cruzi strains and autonomic nervous system pathology in experimental Chagas disease," Memórias do Instituto Oswaldo Cruz, vol. 91, no. 2, pp. 217-224, 1996.

[11] S. J. Adad, C. G. Cançado, R. M. Etchebehere et al., "Neuron count reevaluation in the myenteric plexus of chagasic megacolon after morphometric neuron analysis," Virchows Archiv, vol. 438, no. 3, pp. 254-258, 2001.

[12] Z. A. Andrade and S. G. Andrade, "Immunochemical study of experimental Chagas' disease," Revista do Instituto de Medicina Tropical de São Paulo, vol. 11, no. 1, pp. 44-47, 1969.

[13] A. B. M. da Silveira, S. J. Adad, R. Correa-Oliveira, J. B. Furness, and D. D'Avila Reis, "Morphometric study of eosinophils, mast cells, macrophages and fibrosis in the colon of chronic chagasic patients with and without megacolon," Parasitology, vol. 134, no. 6, pp. 789-796, 2007.

[14] A. B. M. da Silveira, R. M. E. Arantes, A. R. Vago et al., "Comparative study of the presence of Trypanosoma cruzik DNA, inflammation and denervation in chagasic patients with and without megaesophagus," Parasitology, vol. 131, no. 5, pp. 627-634, 2005.

[15] A. B. M. da Silveira, E. M. Lemos, S. J. Adad, R. Correa-Oliveira, J. B. Furness, and D. D'Avila Reis, "Megacolon in Chagas disease: a study of inflammatory cells, enteric nerves, and glial cells," Human Pathology, vol. 38, no. 8, pp. 1256-1264, 2007.

[16] B. M. Ribeiro, E. Crema, and V. Rodrigues Jr., "Analysis of the cellular immune response in patients with the digestive and indeterminate forms of Chagas' disease," Human Immunology, vol. 69, no. 8, pp. 484-489, 2008.

[17] M. M. Camargo, A. C. Andrade, I. C. Almeida, L. R. Travassos, and R. T. Gazzinelli, "Glycoconjugates isolated from Trypanosoma cruzi but not from Leishmania species membranes trigger nitric oxide synthesis as well as microbicidal activity in IFN-gamma-primed macrophages," Journal of Immunology, vol. 159, no. 12, 1997.

[18] B. Basso, "Modulation of immune response in experimental Chagas disease," World J Exp Med, vol. 3, no. 1, pp. 1-10, 2013.

[19] J. E. Yuste, E. Tarragon, C. M. Campuzano, and F. Ros-Bernal, "Implications of glial nitric oxide in neurodegenerative diseases," Frontiers in Cellular Neuroscience, vol. 9, p. 322, 2015.

[20] F. Ochoa-Cortes, F. Turco, A. Linan-Rico et al., "Enteric glial cells: a new frontier in neurogastroenterology and clinical target for inflammatory bowel diseases," Inflamm Bowel Dis, vol. 22, no. 2, pp. 433-449, 2016.

[21] A. B. M. da Silveira, M. A. R. Freitas, E. C. de Oliveira et al., "Glial fibrillary acidic protein and S-100 colocalization in the enteroglial cells in dilated and nondilated portions of colon from chagasic patients," Hum Pathol, vol. 40, no. 2, pp. 244-251, 2009.

[22] R. M. E. Arantes, H. H. F. Marche, M. T. Bahia, F. Q. Cunha, M. A. Rossi, and J. S. Silva, "Interferon- $\gamma$-induced nitric oxide causes intrinsic intestinal denervation in Trypanosoma cruziinfected mice," Am J Pathol, vol. 164, no. 4, pp. 1361-1368, 2004.

[23] J. R. da, M. E. R. S. Camargos, E. Chiari, and C. R. S. Machado, "Trypanosoma cruzi infection and the rat central nervous system: proliferation of parasites in astrocytes and the brain reaction to parasitism," Brain Res Bull, vol. 53, no. 2, pp. 153-162, 2000.

[24] J. E. H. Pittella, "Central nervous system involvement in experimental Trypanosomiasis cruzi," Memórias do Instituto Oswaldo Cruz, vol. 86, no. 2, pp. 141-145, 1991.

[25] E. Villela and E. Villela, "Elementos do sistema nervoso central parasitados pelo Trypanosoma cruzi," Mem Inst Oswaldo Cruz, vol. 26, no. 1, pp. 77-81, 1932.

[26] P. Jackson and R. J. Thompson, "The demonstration of new human brain-specific proteins by high-resolution twodimensional polyacrylamide gel electrophoresis," J Neurol Sci, vol. 49, no. 3, pp. 429-438, 1981.

[27] R. J. Thompson, J. F. Doran, P. Jackson, A. P. Dhillon, and J. Rode, "PGP 9.5-a new marker for vertebrate neurons and neuroendocrine cells," Brain Res, vol. 278, no. 1-2, pp. 224228, 1983.

[28] Y. Watanabe, F. Ito, H. Ando et al., "Morphological investigation of the enteric nervous system in Hirschsprung's disease and hypoganglionosis using whole-mount colon preparation," J Pediatr Surg, vol. 34, no. 3, pp. 445-449, 1999.

[29] D. de Fontgalland, S. J. Brookes, I. Gibbins, T. C. Sia, and D. A. Wattchow, "The neurochemical changes in the innervation of human colonic mesenteric and submucosal blood vessels in ulcerative colitis and Crohn's disease," Neurogastroenterol Motil, vol. 26, no. 5, pp. 731-744, 2014.

[30] H. J. Krammer, W. Meier-Ruge, W. Sigge, R. Eggers, and W. Kühnel, "Histopathological features of neuronal intestinal dysplasia of the plexus submucosus in whole mounts revealed by immunohistochemistry for PGP 9.5," Eur J Pediatr Surg, vol. 4, no. 6, pp. 358-361, 1994.

[31] L. Ny, K. Persson, B. Larsson et al., "Localization and activity of nitric oxide synthases in the gastrointestinal tract of Trypanosoma cruzi-infected mice," J Neuroimmunol, vol. 99, no. 1, pp. 27-35, 1999.

[32] V. Kannen, J. Y. Sakita, Z. A. Carneiro et al., "Mast cells and serotonin synthesis modulate Chagas disease in the colon: clinical and experimental evidence," Dig Dis Sci, vol. 63, no. 6, pp. 1473-1484, 2018.

[33] C. F. Campos, S. D. Cangussú, A. L. C. Duz et al., "Correction: Enteric neuronal damage, intramuscular denervation and smooth muscle phenotype changes as mechanisms of chagasic megacolon: evidence from a long-term murine model of Tripanosoma cruzi infection," PLoS One, vol. 12, no. 4, article e0176224, 2017.

[34] P. R. Martins, R. D. Nascimento, A. T. dos Santos, E. C. de Oliveira, P. M. Martinelli, and D. d'Avila Reis, "Mast cellnerve interaction in the colon of Trypanosoma cruzi-infected individuals with chagasic megacolon," Parasitol Res, vol. 117, no. 4, pp. 1147-1158, 2018.

[35] A. Moncla, F. Landon, M. G. Mattei, and M. M. Portier, "Chromosomal localisation of the mouse and human peripherin genes,” Genet Res, vol. 59, no. 2, pp. 125-129, 1992.

[36] L. M. Parysek and R. D. Goldman, "Characterization of intermediate filaments in PC12 cells," J Neurosci, vol. 7, no. 3, pp. 781-791, 1987.

[37] B. A. Brody, C. A. Ley, and L. M. Parysek, "Selective distribution of the $57 \mathrm{kDa}$ neural intermediate filament protein in the rat CNS," J Neurosci, vol. 9, no. 7, pp. 2391-2401, 1989.

[38] E. M. Hol and Y. Capetanaki, "Type III intermediate filaments desmin, glial fibrillary acidic protein (GFAP), 
vimentin, and peripherin," Cold Spring Harbor Perspectives in Biology, vol. 9, no. 12, 2017.

[39] S. Xiao, J. McLean, and J. Robertson, "Neuronal intermediate filaments and ALS: a new look at an old question," Biochimica et Biophysica Acta - Molecular Basis of Disease, vol. 1762, no. 11-12, pp. 1001-1012, 2006.

[40] R. K. H. Liem and A. Messing, "Dysfunctions of neuronal and glial intermediate filaments in disease," Journal of Clinical Investigation, vol. 119, no. 7, pp. 1814-1824, 2009.

[41] J. McLean, H. N. Liu, D. Miletic et al., "Distinct biochemical signatures characterize peripherin isoform expression in both traumatic neuronal injury and motor neuron disease," $J \mathrm{Neu}$ rochem, vol. 114, no. 4, pp. 1177-1192, 2010.

[42] K. S. Eriksson, S. Zhang, L. Lin, R. C. Larivière, J. P. Julien, and E. Mignot, "The type III neurofilament peripherin is expressed in the tuberomammillary neurons of the mouse," BMC Neurosci, vol. 9, no. 1, p. 26, 2008.

[43] C. M. Leeth, J. Racine, H. D. Chapman et al., "B-lymphocytes expressing an Ig specificity recognizing the pancreatic $\beta$-cell autoantigen peripherin are potent contributors to type 1 diabetes development in NOD mice," Diabetes, vol. 65, no. 7, pp. 1977-1987, 2016.

[44] T. M. Doran, J. Morimoto, S. Simanski et al., "Discovery of phosphorylated peripherin as a major humoral autoantigen in type 1 diabetes mellitus," Cell Chem Biol, vol. 23, no. 5, pp. 618-628, 2016.

[45] A. Brehmer, H. Rupprecht, and W. Neuhuber, "Two submucosal nerve plexus in human intestines," Histochem Cell Biol, vol. 133, no. 2, pp. 149-161, 2010.

[46] K. M. Chisholm and T. A. Longacre, "Utility of peripherin versus MAP-2 and calretinin in the evaluation of Hirschsprung disease," Appl Immunohistochem Mol Morphol, vol. 24, no. 9, pp. 627-632, 2016.

[47] S. K. Holland, R. B. Hessler, M. D. Reid-Nicholson, P. Ramalingam, and J. R. Lee, "Utilization of peripherin and S-100 immunohistochemistry in the diagnosis of Hirschsprung disease," Mod Pathol, vol. 23, no. 9, pp. 1173-1179, 2010.

[48] K. Kramer, A. B. M. da Silveira, S. Jabari, M. Kressel, M. Raab, and A. Brehmer, "Quantitative evaluation of neurons in the mucosal plexus of adult human intestines," Histochemistry and Cell Biology, vol. 136, no. 1, pp. 1-9, 2011.

[49] A. Barcelos Morais da Silveira, E. C. de Oliveira, S. G. Neto et al., "Enteroglial cells act as antigen-presenting cells in chagasic megacolon," Hum Pathol, vol. 42, no. 4, pp. 522-532, 2011.

[50] M. D. Moreira, A. Brehmer, E. C. de Oliveira et al., "Regenerative process evaluation of neuronal subclasses in chagasic patients with megacolon," Hum Immunol, vol. 74, no. 2, pp. 181-188, 2013.

[51] L. Sunesson, U. Hellman, and C. Larsson, "Protein kinase Ce binds peripherin and induces its aggregation, which is accompanied by apoptosis of neuroblastoma cells," J Biol Chem, vol. 283, no. 24, pp. 16653-16664, 2008.

[52] H. J. Okano and R. B. Darnell, "A hierarchy of Hu RNA binding proteins in developing and adult neurons," J Neurosci, vol. 17, no. 9, pp. 3024-3037, 1997.

[53] M. D. Gershon, "Behind an enteric neuron there may lie a glial cell," Journal of Clinical Investigation, vol. 121, no. 9, pp. 3386-3389, 2011.

[54] Z. Lin, N. Gao, H. Z. Hu et al., "Immunoreactivity of Hu proteins facilitates identification of myenteric neurones in guinea-pig small intestine," Neurogastroenterol Motil, vol. 14, no. 2, pp. 197-204, 2002.

[55] R. de Giorgio, M. Bovara, G. Barbara et al., "Anti-HuDinduced neuronal apoptosis underlying paraneoplastic gut dysmotility," Gastroenterology, vol. 125, no. 1, pp. 70-79, 2003.

[56] A. B. M. da Silveira, D. D’Avila Reis, E. C. de Oliveira et al., "Neurochemical coding of the enteric nervous system in chagasic patients with megacolon," Dig Dis Sci, vol. 52, no. 10, pp. 2877-2883, 2007.

[57] S. Jabari, A. B. M. da Silveira, E. C. de Oliveira et al., "Selective survival of calretinin- and vasoactive-intestinal-peptide-containing nerve elements in human chagasic submucosa and mucosa," Cell Tissue Res, vol. 349, no. 2, pp. 473-481, 2012.

[58] P. Vento and S. Soinila, "Quantitative comparison of growthassociated protein GAP-43, neuron- specific enolase, and protein gene product 9.5 as neuronal markers in mature human intestine," J Histochem Cytochem, vol. 47, no. 11, pp. 1405-1415, 2016.

[59] U. S. V. Euler and J. H. Gaddum, "An unidentified depressor substance in certain tissue extracts," J Physiol, vol. 72, no. 1, pp. 74-87, 1931.

[60] C. Severini, G. Improta, G. Falconieri-Erspamer, S. Salvadori, and V. Erspamer, "The tachykinin peptide family," Pharmacological Reviews, vol. 54, no. 2, pp. 285-322, 2002.

[61] J. C. Ansel, A. H. Kaynard, C. A. Armstrong, J. Olerud, N. Bunnett, and D. Payan, "Skin-nervous system interactions," J Invest Dermatol, vol. 106, no. 1, pp. 198-204, 1996.

[62] A. Mashaghi, A. Marmalidou, M. Tehrani, P. M. Grace, C. Pothoulakis, and R. Dana, "Neuropeptide substance P and the immune response," Cellular and Molecular Life Sciences, vol. 73, no. 22, pp. 4249-4264, 2016.

[63] W. K. Hon and C. Pothoulakis, "Immunomodulatory properties of substance P: the gastrointestinal system as a model," in Annals of the New York Academy of Sciences, pp. 23-40, Blackwell Publishing Inc., 2006.

[64] M. G. Vannucchi and S. Evangelista, "Neurokinin receptors in the gastrointestinal muscle wall: cell distribution and possible roles," Biomolecular Concepts, vol. 4, no. 3, pp. 221-231, 2013.

[65] T. M. O'Connor, J. O'Connell, D. I. O'Brien, T. Goode, C. P. Bredin, and F. Shanahan, "The role of substance P in inflammatory disease," Journal of Cellular Physiology, vol. 201, no. 2, pp. 167-180, 2004.

[66] M. B. Johnson, A. D. Young, and I. Marriott, "The therapeutic potential of targeting substance P/NK-1R interactions in inflammatory CNS disorders," Front Cell Neurosci, vol. 10, 2017.

[67] D. Renzi, B. Pellegrini, F. Tonelli, C. Surrenti, and A. Calabrò, "Substance P (neurokinin-1) and neurokinin A (neurokinin-2) receptor gene and protein expression in the healthy and inflamed human intestine," Am J Pathol, vol. 157, no. 5, pp. 1511-1522, 2000.

[68] T. R. Koch, J. A. Carney, and L. W. Vay Go, "Distribution and quantitation of gut neuropeptides in normal intestine and inflammatory bowel diseases," Dig Dis Sci, vol. 32, no. 4, pp. 369-376, 1987.

[69] J. V. Weinstock, "Substance P and the regulation of inflammation in infections and inflammatory bowel disease," Acta Physiologica, vol. 213, no. 2, pp. 453-461, 2015.

[70] N. M. Delvalle, C. Dharshika, W. Morales-Soto, D. E. Fried, L. Gaudette, and B. D. Gulbransen, "Communication 
between enteric neurons, glia, and nociceptors underlies the effects of tachykinins on neuroinflammation," Cell Mol Gastroenterol Hepatol, vol. 6, no. 3, pp. 321-344, 2018.

[71] J. M. Ziebell and M. C. Morganti-Kossmann, "Involvement of pro- and anti-inflammatory cytokines and chemokines in the pathophysiology of traumatic brain injury," Neurotherapeutics, vol. 7, no. 1, pp. 22-30, 2010.

[72] P. G. E. Kennedy, J. Rodgers, F. W. Jennings, M. Murray, S. E. Leeman, and J. M. Burke, "A substance P antagonist, RP67,580 , ameliorates a mouse meningoencephalitic response to Trypanosoma brucei brucei," Proceedings of the National Academy of Sciences of the United States of America, vol. 94, no. 8, pp. 4167-4170, 1997.

[73] A. Garza, J. Weinstock, and P. Robinson, "Absence of the $\mathrm{SP} / \mathrm{SP}$ receptor circuitry in the substance P-precursor knockout mice or SP receptor, neurokinin (NK)1 knockout mice leads to an inhibited cytokine response in granulomas associated with murine Taenia crassiceps infection," J Parasitol, vol. 94, no. 6, pp. 1253-1258, 2008.

[74] E. K. Reinke, M. J. Johnson, C. Ling et al., "Substance P receptor mediated maintenance of chronic inflammation in EAE," J Neuroimmunol, vol. 180, no. 1-2, pp. 117-125, 2006.

[75] Q. Li, X. Wu, Y. Yang et al., "Tachykinin NK1 receptor antagonist L-733,060 and substance P deletion exert neuroprotection through inhibiting oxidative stress and cell death after traumatic brain injury in mice," Int J Biochem Cell Biol, vol. 107, pp. 154-165, 2019.

[76] V. S. Chauhan, J. M. Kluttz, K. L. Bost, and I. Marriott, "Prophylactic and therapeutic targeting of the neurokinin-1 receptor limits neuroinflammation in a murine model of pneumococcal meningitis," J Immunol, vol. 186, no. 12, pp. 7255-7263, 2011.

[77] A. B. M. da Silveira, M. A. R. Freitas, E. C. de Oliveira et al., "Substance P and NK1 receptor expression in the enteric nervous system is related to the development of chagasic megacolon," Trans R Soc Trop Med Hyg, vol. 102, no. 11, pp. 1154-1156, 2008.

[78] R. G. Long, A. J. Barnes, D. J. O'Shaughnessy et al., "Neural and hormonal peptides in rectal biopsy specimens from patients with Chagas' disease and chronic autonomic failure," Lancet, vol. 315, no. 8168, pp. 559-562, 1980.

[79] H. O. Almeida, W. L. Tafuri, J. R. Cunha-Melo, L. FreireMaia, P. Raso, and Z. Brener, "Studies on the vesicular component of the Auerbach's plexus and the substance $\mathrm{P}$ content of the mouse colon in the acute phase of the experimental Trypanosoma cruzi infection," Virchows Arch A Pathol Anat Histol, vol. 376, no. 4, pp. 353-360, 1977.

[80] L. B. M. Maifrino, E. A. Liberti, and R. R. de Souza, "Vasoactive-intestinal-peptide- and substance-P-immunoreactive nerve fibres in the myenteric plexus of mouse colon during the chronic phase of Trypanosoma cruzi infection," Ann Trop Med Parasitol, vol. 93, no. 1, pp. 49-56, 1999.

[81] C. A. Maggi, "The effects of tachykinins on inflammatory and immune cells," Regulatory Peptides, vol. 70, no. 2-3, pp. 7590, 1997.

[82] J. V. Weinstock, A. Blum, A. Metwali, D. Elliott, and R. Arsenescu, "IL-18 and IL-12 signal through the NF- $\kappa$ B pathway to induce NK-1R expression on T cells," J Immunol, vol. 170, no. 10, pp. 5003-5007, 2003.

[83] M. Beinborn, A. Blum, L. Hang et al., “TGF- $\beta$ regulates T-cell neurokinin-1 receptor internalization and function," Pro- ceedings of the National Academy of Sciences, vol. 107, no. 9, pp. 4293-4298, 2010.

[84] P. Holzer and U. Holzer-Petsche, "Tachykinins in the gut. Part II. Roles in neural excitation, secretion and inflammation," Pharmacology and Therapeutics, vol. 73, no. 3, pp. 219-263, 1997.

[85] M. R. Holahan, "A shift from a pivotal to supporting role for the growth-associated protein (GAP-43) in the coordination of axonal structural and functional plasticity," Frontiers in Cellular Neuroscience, vol. 11, 2017.

[86] D. Grynspan, A. C. C. Giassi, R. Cadonic et al., "Growth-associated protein-43 (GAP-43) expression in ganglionic and aganglionic colon," Pediatric and Developmental Pathology, vol. 15, 2012.

[87] A. Saeed, L. Barreto, S. G. Neogii, A. Loos, I. Mcfarlane, and A. Aslam, "Identification of novel genes in Hirschsprung disease pathway using whole genome expression study," Journal of Pediatric Surgery, vol. 47, no. 2, pp. 303-307, 2012.

[88] L. CMY, R. K. Kumar, D. Z. Lubowski, and E. Burcher, "Neuropeptides and nerve growth in inflammatory bowel diseases: a quantitative immunohistochemical study," Digestive Diseases and Sciences, vol. 47, no. 3, pp. 495-502, 2002.

[89] P. Di Sebastiano, T. Fink, F. F. di Mola et al., "Neuroimmune appendicitis," The Lancet, vol. 354, no. 9177, pp. 461-466, 1999.

[90] H. Kobayashi, H. Hirakawa, and P. Puri, "Is intestinal neuronal dysplasia a disorder of the neuromuscular junction?," Journal of Pediatric Surgery, vol. 31, no. 4, pp. 575-579, 1996.

[91] R. H. Stead, U. Kosecka-Janiszewska, A. B. Oestreicher, M. F. Dixon, and J. Bienenstock, "Remodeling of B-50 (GAP-43)and NSE-immunoreactive mucosal nerves in the intestines of rats infected with Nippostrongylus brasiliensis," The Journal of Neuroscience, vol. 11, no. 12, pp. 3809-3821, 1991.

[92] A. B. M. da Silveira, M. A. R. Freitas, E. C. de Oliveira et al., "Neuronal plasticity of the enteric nervous system is correlated with chagasic megacolon development," Parasitology, vol. 135, no. 11, pp. 1337-1342, 2008.

[93] A. L. A. Mascaro, P. Cesare, L. Sacconi et al., "In vivo single branch axotomy induces GAP-43-dependent sprouting and synaptic remodeling in cerebellar cortex," Proceedings of the National Academy of Sciences, vol. 110, no. 26, 2013.

[94] W. H. Gispen, J. Boonstra, P. N. E. De Graan et al., "B50/GAP-43 in neuronal development and repair," Restorative Neurology and Neuroscience, vol. 1, no. 3,4, pp. 237-244, 1990.

[95] C. J. Woolf, M. L. Reynolds, C. Molander, C. O’Brien, R. M. Lindsay, and L. I. Benowitz, "The growth-associated protein gap-43 appears in dorsal root ganglion cells and in the dorsal horn of the rat spinal cord following peripheral nerve injury," Neuroscience, vol. 34, no. 2, pp. 465-478, 1990.

[96] P. Yang, H. Wen, S. Ou, J. Cui, and D. Fan, "IL-6 promotes regeneration and functional recovery after cortical spinal tract injury by reactivating intrinsic growth program of neurons and enhancing synapse formation," Experimental Neurology, vol. 236, no. 1, pp. 19-27, 2012.

[97] F. Liu, F. Liao, W. Li, Y. Han, and D. Liao, "Progesterone alters Nogo-A, GFAP and GAP-43 expression in a rat model of traumatic brain injury," Molecular Medicine Reports, vol. 9, no. 4, pp. 1225-1231, 2014.

[98] N. Marklund, F. M. Bareyre, N. C. Royo et al., "Cognitive outcome following brain injury and treatment with an inhibitor 
of Nogo-A in association with an attenuated downregulation of hippocampal growth-associated protein-43 expression," Journal of Neurosurgery, vol. 107, no. 4, pp. 844-853, 2007.

[99] Y. Yang, Y. Liu, P. Wei et al., "Silencing Nogo-A promotes functional recovery in demyelinating disease," Annals of Neurology, vol. 67, no. 4, pp. 498-507, 2010.

[100] D. B. Zimmer, J. O. Eubanks, D. Ramakrishnan, and M. F. Criscitiello, "Evolution of the S100 family of calcium sensor proteins," Cell Calcium, vol. 53, no. 3, pp. 170-179, 2013.

[101] A. R. Bresnick, "S100 proteins as therapeutic targets," Biophysical Reviews, vol. 10, no. 6, pp. 1617-1629, 2018.

[102] R. Donato, B. R. Cannon, G. Sorci et al., "Functions of S100 proteins," Current Molecular Medicine, vol. 13, no. 1, pp. 24-57, 2012.

[103] D. Grundmann, E. Loris, S. Maas-Omlor et al., "Enteric glia: S100, GFAP, and beyond," The Anatomical Record, vol. 302, no. 8, pp. 1333-1344, 2019.

[104] A. E. Bishop, F. Carlei, V. Lee et al., "Combined immunostaining of neurofilaments, neuron specific enolase, GFAP and S-100 - a possible means for assessing the morphological and functional status of the enteric nervous system," Histochemistry, vol. 82, no. 1, pp. 93-97, 1985.

[105] L. Ariel Gomez, A. Brusco, and J. P. Saavedra, "Immunocytochemical study of S-100 positive glial cells in the brainstem and spinal cord of the rat embryo," International Journal of Developmental Neuroscience, vol. 8, no. 1, pp. 55-64, 1990.

[106] G. L. Ferri, L. Probert, D. Cocchia, F. Michetti, P. J. Marangos, and J. M. Polak, "Evidence for the presence of S-100 protein in the glial component of the human enteric nervous system," Nature, vol. 297, no. 5865, pp. 409-410, 1982.

[107] H. J. Krammer, S. T. Karahan, W. Sigge, and W. Kühnel, "Immunohistochemistry of markers of the enteric nervous system in whole-mount preparations of the human colon," European Journal of Pediatric Surgery, vol. 4, no. 5, pp. 274-278, 1994.

[108] D. Li, X. Liu, T. Liu et al., "Neurochemical regulation of the expression and function of glial fibrillary acidic protein in astrocytes," GLIA, vol. 68, no. 5, pp. 878-897, 2020.

[109] L. F. Eng, R. S. Ghirnikar, and Y. L. Lee, "Glial fibrillary acidic protein: GFAP-thirty-one years (1969-2000)," Neurochemical Research, vol. 25, no. 9/10, pp. 1439-1451, 2000.

[110] J. Middeldorp and E. M. Hol, "GFAP in health and disease," Progress in Neurobiology, vol. 93, no. 3, pp. 421-443, 2011.

[111] K. R. Jessen and R. Mirsky, "Glial cells in the enteric nervous system contain glial fibrillary acidic protein," Nature, vol. 286, no. 5774, pp. 736-737, 1980.

[112] M. A. R. Freitas, N. Segatto, Pedro et al., "Neurotrophin expression in chagasic megacolon," JSM Atherosclerosis, vol. 1, no. 3, p. 1013, 2016.

[113] G. Iantorno, G. Bassotti, Z. Kogan et al., "The enteric nervous system in chagasic and idiopathic megacolon," American Journal of Surgical Pathology, vol. 31, no. 3, pp. 460-468, 2007.

[114] S. Jabari, A. B. M. da Silveira, E. C. de Oliveira et al., "Interstitial cells of Cajal: crucial for the development of megacolon in human Chagas' disease?," Colorectal Disease, vol. 15, no. 10, pp. e592-e598, 2013.

[115] A. R. Trevizan, L. C. L. Schneider, E. J. de Almeida Araújo et al., "Acute Toxoplasma gondii infection alters the number of neurons and the proportion of enteric glial cells in the duo- denum in Wistar rats," Neurogastroenterology \& Motility, vol. 31, no. 3, p. e13523, 2019.

[116] M. F. Pavanelli, C. M. Colli, R. C. Bezagio et al., “Assemblages $\mathrm{A}$ and B of Giardia duodenalis reduce enteric glial cells in the small intestine in mice," Parasitology Research, vol. 117, no. 7, pp. 2025-2033, 2018.

[117] C. Cirillo, G. Sarnelli, G. Esposito et al., "Increased mucosal nitric oxide production in ulcerative colitis is mediated in part by the enteroglial-derived S100B protein," Neurogastroenterology \& Motility, vol. 21, no. 11, 2009.

[118] G. D. P. Bossolani, B. T. Silva, J. V. C. M. Perles et al., "Rheumatoid arthritis induces enteric neurodegeneration and jejunal inflammation, and quercetin promotes neuroprotective and anti-inflammatory actions," Life Sciences, vol. 238, article 116956, 2019.

[119] G. B. T. Von Boyen, N. Schulte, C. Pflüger, U. Spaniol, C. Hartmann, and M. Steinkamp, "Distribution of enteric glia and GDNF during gut inflammation," BMC Gastroenterology, vol. 11, no. 1, p. 3, 2011.

[120] S. J. Allen, J. J. Watson, D. K. Shoemark, N. U. Barua, and N. K. Patel, "GDNF, NGF and BDNF as therapeutic options for neurodegeneration," Pharmacology \& Therapeutics, vol. 138, no. 2, pp. 155-175, 2013.

[121] R. Soret, S. Schneider, G. Bernas et al., "Glial cell-derived neurotrophic factor induces enteric neurogenesis and improves colon structure and function in mouse models of Hirschsprung disease," Gastroenterology, vol. 159, no. 5, pp. 18241838.e17, 2020.

[122] C. Cirillo, G. Sarnelli, F. Turco et al., "Proinflammatory stimuli activates human-derived enteroglial cells and induces autocrine nitric oxide production," Neurogastroenterology \& Motility, vol. 23, no. 9, pp. e372-e382, 2011.

[123] G. B. T. Von Boyen, M. Steinkamp, M. Reinshagen, K. H. Schäfer, G. Adler, and J. Kirsch, "Proinflammatory cytokines increase glial fibrillary acidic protein expression in enteric glia," Gut, vol. 53, no. 2, pp. 222-228, 2004.

[124] G. B. von Boyen, M. Steinkamp, I. Geerling et al., "Proinflammatory cytokines induce neurotrophic factor expression in enteric glia," Inflammatory Bowel Diseases, vol. 12, no. 5, pp. 346-354, 2006.

[125] T. G. Bush, T. C. Savidge, T. C. Freeman et al., "Fulminant jejuno-ileitis following ablation of enteric glia in adult transgenic mice," Cell, vol. 93, no. 2, pp. 189-201, 1998.

[126] A. Cornet, T. C. Savidge, J. Cabarrocas et al., "Enterocolitis induced by autoimmune targeting of enteric glial cells: a possible mechanism in Crohn's disease?," Proceedings of the National Academy of Sciences, vol. 98, no. 23, pp. 13306-13311, 2001.

[127] F. Turco, G. Sarnelli, C. Cirillo et al., "Enteroglial-derived S100B protein integrates bacteria-induced Toll-like receptor signalling in human enteric glial cells," Gut, vol. 63, no. 1, pp. 105-115, 2014.

[128] M. Murakami, T. Ohta, and S. Ito, "Lipopolysaccharides enhance the action of bradykinin in enteric neurons via secretion of interleukin- $1 \beta$ from enteric glial cells," Journal of Neuroscience Research, vol. 87, no. 9, pp. 2095-2104, 2009.

[129] A. Rühl, S. Franzke, S. M. Collins, and W. Stremmel, "Interleukin-6 expression and regulation in rat enteric glial cells," American Journal of Physiology-Gastrointestinal and Liver Physiology, vol. 280, no. 6, pp. G1163-G1171, 2001.

[130] Y. Yuan, C. Wu, and E.-A. Ling, "Heterogeneity of microglia phenotypes: developmental, functional and some therapeutic 
considerations," Current Pharmaceutical Design, vol. 25, no. 21, pp. 2375-2393, 2019.

[131] D. Atiakshin, I. Buchwalow, V. Samoilova, and M. Tiemann, "Tryptase as a polyfunctional component of mast cells," Histochemistry and Cell Biology, vol. 149, no. 5, pp. 461-477, 2018.

[132] D. Atiakshin, I. Buchwalow, and M. Tiemann, "Mast cell chymase: morphofunctional characteristics," Histochemistry and Cell Biology, vol. 152, no. 4, pp. 253-269, 2019.

[133] J. Li, S. Jubair, S. P. Levick, and J. S. Janicki, "The autocrine role of tryptase in pressure overload-induced mast cell activation, chymase release and cardiac fibrosis," IJC Metabolic \& Endocrine, vol. 10, pp. 16-23, 2016.

[134] H. Tan, Z. Chen, F. Chen et al., "Tryptase promotes the profibrotic phenotype transfer of atrial fibroblasts by PAR2 and PPAR $\gamma$ pathway," Archives of Medical Research, vol. 49, no. 8, pp. 568-575, 2018.

[135] M. W. Kofford, L. B. Schwartz, N. M. Schechter, D. R. Yager, R. F. Diegelmann, and M. F. Graham, "Cleavage of type I procollagen by human mast cell chymase initiates collagen fibril formation and generates a unique carboxyl-terminal propeptide," Journal of Biological Chemistry, vol. 272, no. 11, pp. 7127-7131, 1997.

[136] D. Kosanovic, H. Luitel, B. K. Dahal et al., "Chymase: a multifunctional player in pulmonary hypertension associated with lung fibrosis," European Respiratory Journal, vol. 46, no. 4, pp. 1084-1094, 2015.

[137] G. H. Caughey, "Mast cell proteases as protective and inflammatory mediators," Advances in Experimental Medicine and Biology, vol. 716, pp. 212-234, 2011.

[138] M. A. R. Freitas, N. Segatto, N. Tischler, E. C. de Oliveira, A. Brehmer, and A. B. M. Da Silveira, "Relation between mast cells concentration and serotonin expression in chagasic megacolon development," Parasite Immunology, vol. 39, no. 3, article e12414, 2017.

[139] S. W. Pinheiro, A. M. de Oliveira Rua, R. M. Etchebehere et al., "Morphometric study of the fibrosis and mast cell count in the circular colon musculature of chronic Chagas patients with and without megacolon," Revista da Sociedade Brasileira de Medicina Tropical, vol. 36, no. 4, pp. 461-466, 2003.

[140] C. F. Campos, S. D. Cangussú, A. L. C. Duz et al., "Enteric neuronal damage, intramuscular denervation and smooth muscle phenotype changes as mechanisms of chagasic megacolon: evidence from a long-term murine model of tripanosoma cruzi infection," PLoS One, vol. 11, no. 4, 2016.

[141] D. E. Reed, C. Barajas-Lopez, G. Cottrell et al., "Mast cell tryptase and proteinase-activated receptor 2 induce hyperexcitability of guinea-pig submucosal neurons," The Journal of Physiology, vol. 547, no. 2, pp. 531-542, 2003.

[142] L. Zhang, J. Song, T. Bai, R. Wang, and X. Hou, "Sustained pain hypersensitivity in the stressed colon: role of mast cellderived nerve growth factor-mediated enteric synaptic plasticity," Neurogastroenterology \& Motility, vol. 30, no. 9, article e13430, 2018.

[143] D. Ostertag, A. Annahazi, D. Krueger et al., "Tryptase potentiates enteric nerve activation by histamine and serotonin: relevance for the effects of mucosal biopsy supernatants from irritable bowel syndrome patients," Neurogastroenterology \& Motility, vol. 29, no. 9, article e13070, 2017.

[144] K. Mueller, K. Michel, D. Krueger et al., "Activity of proteaseactivated receptors in the human submucous plexus," Gastroenterology, vol. 141, no. 6, pp. 2088-2097.e1, 2011.
[145] F. Wang, T. L. B. Yang, and B. S. Kim, "The return of the mast cell: new roles in neuroimmune itch biology," Journal of Investigative Dermatology, vol. 140, no. 5, pp. 945-951, 2020.

[146] E. Sand, A. Themner-Persson, and E. Ekblad, "Mast cells reduce survival of myenteric neurons in culture," Neuropharmacology., vol. 56, no. 2, pp. 522-530, 2009.

[147] M. Kulka, C. H. Sheen, B. P. Tancowny, L. C. Grammer, and R. P. Schleimer, "Neuropeptides activate human mast cell degranulation and chemokine production," Immunology, vol. 123, no. 3, pp. 398-410, 2008.

[148] S. Ständer, H. Ständer, S. Seeliger, T. A. Luger, and M. Steinhoff, "Topical pimecrolimus and tacrolimus transiently induce neuropeptide release and mast cell degranulation in murine skin," British Journal of Dermatology, vol. 156, no. 5, pp. 1020-1026, 2007.

[149] X. Pang, W. Boucher, G. Triadafilopoulos, G. R. Sant, and T. C. Theoharides, "Mast cell and substance P-positive nerve involvement in a patient with both irritable bowel syndrome and interstitial cystitis," Urology, vol. 47, no. 3, pp. 436-438, 1996.

[150] J. Cairns and A. Walls, "Mast cell tryptase is a mitogen for epithelial cells. Stimulation of IL-8 production and intercellular adhesion molecule-1 expression," The Journal of Immunology, vol. 156, no. 1, pp. 275-283, 1996.

[151] N. Vergnolle, M. D. Hollenberg, K. A. Sharkey, and J. L. Wallace, "Characterization of the inflammatory response to proteinase-activated receptor-2 (PAR2)-activating peptides in the rat paw," British Journal of Pharmacology, vol. 127, no. 5, pp. 1083-1090, 1999.

[152] M. C. Meyer, M. H. Creer, and J. McHowat, "Potential role for mast cell tryptase in recruitment of inflammatory cells to endothelium," American Journal of Physiology-Cell Physiology, vol. 289, no. 6, pp. C1485-C1491, 2005.

[153] M. E. M. S. Khedr, A. M. Abdelmotelb, S. L. F. Pender, X. Zhou, and A. F. Walls, "Neutrophilia, gelatinase release and microvascular leakage induced by human mast cell tryptase in a mouse model: lack of a role of protease-activated receptor 2 (PAR2)," Clinical \& Experimental Allergy, vol. 48, no. 5, pp. 555-567, 2018.

[154] N. A. Matos, J. F. Silva, T. C. Matsui et al., "Mast cell tryptase induces eosinophil recruitment in the pleural cavity of mice via proteinase-activated receptor 2," Inflammation, vol. 36, no. 6, pp. 1260-1267, 2013.

[155] F. Schmidlin, S. Amadesi, K. Dabbagh et al., "Protease-activated receptor 2 mediates eosinophil infiltration and hyperreactivity in allergic inflammation of the airway," The Journal of Immunology, vol. 169, no. 9, pp. 5315-5321, 2002.

[156] M. R. Namazi, "Possible molecular mechanisms to account for the involvement of tryptase in the pathogenesis of psoriasis," Autoimmunity, vol. 38, no. 6, pp. 449-452, 2005.

[157] G. Lezmi, L. Galmiche-Rolland, S. Rioux et al., "Mast cells are associated with exacerbations and eosinophilia in children with severe asthma," European Respiratory Journal, vol. 48, no. 5, pp. 1320-1328, 2016.

[158] P. R. Martins, R. D. Nascimento, J. G. Lopes et al., "Mast cells in the colon of Trypanosoma cruzi-infected patients: are they involved in the recruitment, survival and/or activation of eosinophils?" Parasitology Research, vol. 114, no. 5, pp. 1847-1856, 2015.

[159] M. R. Galdiero, G. Varricchi, M. Seaf, G. Marone, F. LeviSchaffer, and G. Marone, "Bidirectional mast cell-eosinophil 
interactions in inflammatory disorders and cancer," Frontiers in Medicine, vol. 4, 2017.

[160] M. Elishmereni, H. T. Alenius, P. Bradding et al., "Physical interactions between mast cells and eosinophils: a novel mechanism enhancing eosinophil survival in vitro," Allergy, vol. 66, no. 3, pp. 376-385, 2011.

[161] J. D. de Boer, J. Yang, F. E. van den Boogaard et al., "Mast celldeficient KitW-sh mice develop house dust mite-induced lung inflammation despite impaired eosinophil recruitment," Journal of Innate Immunity, vol. 6, no. 2, pp. 219-226, 2014.

[162] H. A. Molina, K. J. Hamann, G. J. Gleich, and F. Kierszenbaum, "Toxic effects produced or mediated by human eosinophil granule components on Trypanosoma cruzi," The American Journal of Tropical Medicine and Hygiene, vol. 38, no. 2, pp. 327-334, 1988.

[163] H. A. Molina and F. Kierszenbaum, "Immunohistochemical detection of deposits of eosinophil-derived neurotoxin and eosinophil peroxidase in the myocardium of patients with Chagas' disease," Immunology, vol. 64, no. 4, pp. 725-731, 1988.

[164] H. A. Molina and F. Kierszenbaum, "Interaction of human eosinophils or neutrophils with Trypanosoma cruzi in vitro causes bystander cardiac cell damage," Immunology, vol. 66, no. 2, pp. 289-295, 1989.

[165] F. Villalta and F. Kierszenbaum, "Role of inflammatory cells in Chagas' disease. I. Uptake and mechanism of destruction of intracellular (amastigote) forms of Trypanosoma cruzi by human eosinophils," The Journal of Immunology, vol. 132, no. 4, pp. 2053-2058, 1984.

[166] F. Kierszenbaum, G. J. Gleich, and S. J. Ackerman, "Destruction of bloodstream forms of Trypanosoma cruzi by eosinophil granule major basic protein," The American Journal of Tropical Medicine and Hygiene, vol. 30, no. 4, pp. 775-779, 1981.

[167] M. C. Nakhle, M. D. C. S. de Menezes, and I. Irulegui, "Eosinophil levels in the acute phase of experimental Chagas' disease," Revista do Instituto de Medicina Tropical de São Paulo, vol. 31, no. 6, pp. 384-391, 1989.

[168] G. A. N. Nascentes, W. S. F. Meira, E. Lages-Silva, and L. E. Ramírez, "Immunization of mice with a Trypanosoma cruzi-like strain isolated from a bat: predictive factors for involvement of eosinophiles in tissue damage," Vector-Borne and Zoonotic Diseases, vol. 10, no. 10, pp. 989-997, 2010.

[169] A. Andoh, Y. Deguchi, O. Inatomi et al., "Immunohistochemical study of chymase-positive mast cells in inflammatory bowel disease," Oncology Reports, vol. 16, no. 1, pp. 103-107, 2006.

[170] Z. Li, D. Peirasmaki, S. Svärd, and M. Åbrink, "The chymase mouse mast cell protease- 4 regulates intestinal cytokine expression in mature adult mice infected with Giardia intestinalis," Cells, vol. 9, no. 4, p. 925, 2020.

[171] C. E. Lawrence, Y. Y. W. Paterson, S. H. Wright, P. A. Knight, and H. R. P. Miller, "Mouse mast cell protease-1 is required for the enteropathy induced by gastrointestinal helminth infection in the mouse," Gastroenterology, vol. 127, no. 1, pp. 155-165, 2004.

[172] H. Serna, M. Porras, and P. Vergara, "Mast cell stabilizer ketotifen [4-(1-methyl-4-piperidylidene)-4H-benzo[4,5]cyclohepta[1,2-b]thiophen-10(9H)-one fumarate] prevents mucosal mast cell hyperplasia and intestinal dysmotility in experimental Trichinella spiralis inflammation in the rat," Journal of Pharma- cology and Experimental Therapeutics, vol. 319, no. 3, pp. 11041111, 2006.

[173] E.-Y. Cho, S.-C. Choi, S.-H. Lee et al., "Nafamostat mesilate attenuates colonic inflammation and mast cell infiltration in the experimental colitis," International Immunopharmacology, vol. 11, no. 4, pp. 412-417, 2011.

[174] W. X. Liu, Y. Wang, L. X. Sang et al., "Chymase inhibitor TY51469 in therapy of inflammatory bowel disease," World Journal of Gastroenterology, vol. 22, no. 5, pp. 1826-1833, 2016.

[175] Y. Li, Z. Song, K. A. Kerr, and A. J. Moeser, "Chronic social stress in pigs impairs intestinal barrier and nutrient transporter function, and alters neuro-immune mediator and receptor expression," PLoS One, vol. 12, no. 2, 2017.

[176] A. M. Piliponsky, C.-C. Chen, E. J. Rios et al., "The chymase mouse mast cell protease 4 degrades TNF, limits inflammation, and promotes survival in a model of sepsis," The American Journal of Pathology, vol. 181, no. 3, pp. 875-886, 2012.

[177] S. Takai, D. Jin, and M. Miyazaki, "Multiple mechanisms for the action of chymase inhibitors," Journal of Pharmacological Sciences, vol. 118, no. 3, pp. 311-316, 2012.

[178] L. J. Dell'italia, J. F. Collawn, and C. M. Ferrario, "Multifunctional role of chymase in acute and chronic tissue injury and remodeling," Circulation Research, vol. 122, no. 2, pp. 319336, 2018.

[179] G. G. Caballero, H. Kaltner, T. J. Kutzner et al., "How galectins have become multifunctional proteins," Histology and Histopathology, vol. 35, no. 6, pp. 509-539, 2020.

[180] P. Demetter, N. Nagy, B. Martin et al., "The galectin family and digestive disease," The Journal of Pathology, vol. 215, no. 1, pp. 1-12, 2008.

[181] C. G. Barbosa, T. M. C. Costa, C. S. Desidério et al., “Trypanosoma cruzi mexican strains differentially modulate surface markers and cytokine production in bone marrow-derived dendritic cells from C57BL/6 and BALB/c mice," Mediators of Inflammation, vol. 2019, Article ID 7214798, 14 pages, 2019.

[182] M. Beghini, M. F. de Araújo, V. O. Severino, R. M. Etchebehere, D. B. Rocha Rodrigues, and S. A. de Lima Pereira, "Evaluation of the immunohistochemical expression of Gal-1, Gal-3 and Gal-9 in the colon of chronic chagasic patients," Pathology Research and Practice, vol. 213, no. 9, pp. 1207-1214, 2017.

[183] M. P. Garvil, T. C. de Souza Furtado, N. B. de Lima et al., "Although with intact mucosa at colonoscopy, chagasic megacolons have an overexpression of Gal-3," Einstein, vol. 18, article eAO5105, 2020.

[184] A. F. Benatar, G. A. García, J. Bua et al., "Galectin-1 prevents infection and damage induced by Trypanosoma cruzi on cardiac cells," PLOS Neglected Tropical Diseases, vol. 9, no. 10, article e0004148, 2015.

[185] C. V. Poncini, J. M. Ilarregui, E. I. Batalla et al., "Trypanosoma cruzi infection imparts a regulatory program in dendritic cells and T cells via galectin-1-dependent mechanisms," The Journal of Immunology, vol. 195, no. 7, pp. 3311-3324, 2015.

[186] H.-L. Chen, F. Liao, T.-N. Lin, and F.-T. Liu, "Galectins and neuroinflammation," Springer, New York, NY, USA, 2014.

[187] M. A. Toscano, G. A. Bianco, J. M. Ilarregui et al., "Differential glycosylation of TH1, TH2 and TH-17 effector cells selectively regulates susceptibility to cell death," Nature Immunology, vol. 8, no. 8, pp. 825-834, 2007.

[188] C. Zhu, A. C. Anderson, A. Schubart et al., "The Tim-3 ligand galectin-9 negatively regulates T helper type 1 immunity," Nature Immunology, vol. 6, no. 12, pp. 1245-1252, 2005. 
[189] S. C. Starossom, I. . D. Mascanfroni, J. Imitola et al., "Galectin-1 deactivates classically activated microglia and protects from inflammation-induced neurodegeneration," Immunity, vol. 37, no. 2, pp. 249-263, 2012.

[190] H. Horie, T. Kadoya, N. Hikawa et al., "Oxidized galectin-1 stimulates macrophages to promote axonal regeneration in peripheral nerves after axotomy," Journal of Neuroscience, vol. 24, no. 8, pp. 1873-1880, 2004.

[191] H.-Y. Chen, B. B. Sharma, L. Yu et al., "Role of galectin-3 in mast cell functions: galectin-3-deficient mast cells exhibit impaired mediator release and defective JNK expression," The Journal of Immunology, vol. 177, no. 8, pp. 4991-4997, 2006.

[192] H.-R. Jiang, Z. Al Rasebi, E. Mensah-Brown et al., "Galectin-3 deficiency reduces the severity of experimental autoimmune encephalomyelitis," The Journal of Immunology, vol. 182, no. 2, pp. 1167-1173, 2009.

[193] X. Cheng, A. Boza-Serrano, M. F. Turesson, T. Deierborg, E. Ekblad, and U. Voss, "Galectin-3 causes enteric neuronal loss in mice after left sided permanent middle cerebral artery occlusion, a model of stroke," Scientific Reports, vol. 6, no. 1, 2016.

[194] I. Srejovic, D. Selakovic, N. Jovicic, V. Jakovljević, M. L. Lukic, and G. Rosic, "Galectin-3: roles in neurodevelopment, neuroinflammation, and behavior," Biomolecules, vol. 10, no. 5, p. 798, 2020.

[195] G. Reid and M. Rand, "Physiological actions of the partially purified serum vasoconstrictor (serotonin)," Australian Journal of Experimental Biology and Medical Science, vol. 29, no. 6, pp. 401-415, 1951.

[196] J. Lv and F. Liu, "The role of serotonin beyond the central nervous system during embryogenesis," Frontiers in Cellular Neuroscience, vol. 11, 2017.

[197] M. D. Gershon, "Serotonin: its role and receptors in enteric neurotransmission," Advances in Experimental Medicine and Biology, vol. 294, pp. 221-230, 1991.

[198] R. Mittal, L. H. Debs, A. P. Patel et al., "Neurotransmitters: the critical modulators regulating gut-brain axis," Journal of Cellular Physiology, vol. 232, no. 9, pp. 2359-2372, 2017.

[199] M. D. Gershon, A. B. Drakontides, and L. L. Ross, "Serotonin: synthesis and release from the myenteric plexus of the mouse intestine.," Science, vol. 149, no. 3680, pp. 197-199, 1965.

[200] M. D. Gershon and J. Tack, "The serotonin signaling system: from basic understanding to drug development for functional GI disorders," Gastroenterology, vol. 132, no. 1, pp. 397-414, 2007.

[201] P.-L. Yu, M. Fujimura, K. Okumiya, M. Kinoshita, H. Hasegawa, and M. Fujimiya, "Immunohistochemical localization of tryptophan hydroxylase in the human and rat gastrointestinal tracts," The Journal of Comparative Neurology, vol. 411, no. 4, pp. 654-665, 1999.

[202] M. S. Shajib and W. I. Khan, "The role of serotonin and its receptors in activation of immune responses and inflammation," Acta Physiologica, vol. 213, no. 3, pp. 561-574, 2015.

[203] A. Y. Thijssen, Z. Mujagic, D. M. A. E. Jonkers et al., “Alterations in serotonin metabolism in the irritable bowel syndrome," Alimentary Pharmacology \& Therapeutics, vol. 43, no. 2, pp. 272-282, 2016.

[204] M. S. Shajib, U. Chauhan, S. Adeeb et al., "Characterization of serotonin signaling components in patients with inflammatory bowel disease," Journal of the Canadian Association of Gastroenterology, vol. 2, no. 3, pp. 132-140, 2019.
[205] N. S. Coleman, S. Foley, S. P. Dunlop et al., "Abnormalities of serotonin metabolism and their relation to symptoms in untreated celiac disease," Clinical Gastroenterology and Hepatology, vol. 4, no. 7, pp. 874-881, 2006.

[206] C. P. Bearcroft, D. Perrett, and M. J. Farthing, "5-Hydroxytryptamine release into human jejunum by cholera toxin," Gut., vol. 39, no. 4, pp. 528-531, 1996.

[207] J. L. Turvill, P. Connor, and M. J. G. Farthing, "The inhibition of cholera toxin-induced 5-HT release by the 5-HT3receptor antagonist, granisetron, in the rat," British Journal of Pharmacology, vol. 130, no. 5, pp. 1031-1036, 2000.

[208] M. L. Grøndahl, G. M. Jensen, C. G. Nielsen, E. Skadhauge, J. E. Olsen, and M. B. Hansen, "Secretory pathways in Salmonella Typhimurium-induced fluid accumulation in the porcine small intestine," Journal of Medical Microbiology, vol. 47, no. 2, pp. 151-157, 1998.

[209] J. Wheatcroft, D. Wakelin, A. Smith, C. R. Mahoney, G. Mawe, and R. Spiller, "Enterochromaffin cell hyperplasia and decreased serotonin transporter in a mouse model of postinfectious bowel dysfunction," Neurogastroenterology and Motility, vol. 17, no. 6, pp. 863-870, 2005.

[210] R. Spiller, "Serotonin and GI clinical disorders," Neuropharmacology, vol. 55, no. 6, pp. 1072-1080, 2008.

[211] M. A. R. de Freitas, E. C. de Oliveira, F. C. de Oliveira, S. Jabari, A. Brehmer, and A. B. M. da Silveira, "Is the increased presence of CD8 T-lymphocytes related to serotonin levels in Chagas disease?," Colorectal Disease, vol. 17, no. 3, pp. 268-269, 2015.

[212] J. A. de Oliveira, M. A. R. Freitas, E. C. de Oliveira, S. Jabari, A. Brehmer, and A. B. M. Da Silveira, "5-HT3A serotonin receptor in the gastrointestinal tract: the link between immune system and enteric nervous system in the digestive form of Chagas disease," Parasitology Research, vol. 118, no. 4, pp. 1325-1329, 2019. 